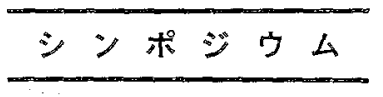

\title{
第4 回日本ウイルス学会九州支部総会記録
}

昭和 42 年 5 月 27 日

（佐世保市長崎県北開発振興局大会議室）

総会長 中川洋教授

\section{シンポジウムI}

腹部症状老伴うるエロニユーロパティ

$$
\text { 司会中川洋 (久留米大学) }
$$
1. 臨床
奥 田邦 雄 (久留米大学)
2. 殓断子绶学
大村一郎(與国立病院)
3. 病理
三四哲 可 (九州大学)
4. 病因
新宾 正久 (久留米大学)

\section{特 別講 演}

呼吸器ウイルス感染症—特にライノウィルス屏中心として一一

$$
\text { 川名 林 治(岩手医科大学) }
$$

\section{ポジウム II}

ウイルス病己免疫

\section{司会 六反田藤吉 (熊本大学)}

1. 称疹

2, 日本脳炎

3. インフルエンザ

4. 胸腺乙ウイルス感染症

5。風疹ウイルス

$$
\begin{aligned}
& \text { 船 津維一郎 (久留米大学) } \\
& \text { 貴“田丈”夫(熊本大学) } \\
& \text { 高橋，克 巨(長㥓県衛生研究所) } \\
& \text { 大嫁、悟:(福烊紧衛生研究所) } \\
& \text { 加 地 正郎 (九州大学) , } \\
& \text { 不田弘(化血研) } \\
& \text { 森良一(九州大学) } \\
& \text { 植田浩司(九州大学) }
\end{aligned}
$$

\section{シンポジウム 1}

\section{腹部症状を伴うミエロニューロパティ}

\section{1. 臨床}

久留米大学医学部第二内科

奥. 田、邦 雄

腹部症状に続発する脑盗髄炎法 昭和 34 年頃汃方本邦
に增加し，昭和 36 年に三重の高崎が慢性腸炎に対し麻 痻を起した患者を始めて記載したのに始まる，その後色 々の地区から同様な患者の発生が報告され，今までに記 載のなかつた新しい疾患しして昭和 40 年内科学会シン ポジウムの議題として取り上げられた。又その原因を突 きとめるために厚生省研究班も作られ，多方面にわたつ て研究がなされている。

われわ和的欠留米市老中心とした地域で発病した本症 
患者ならびに類似疾患約 70 例を経験したが，その中で 厳格な規準にてらして診断した 52 例を中心亡して述心゙ る.

神経症状に前駆する腹部症状としては腹痛と下浰と同 時に訴えた者が 22 例めり，腹痛の文は 9 例，下痢のみ は 10 例，便秘は 2 例であつた。席の性状は多くは水 様または軟便であり，舟便は 4 例记認めた。

年齢，性別：年齢的には 40 60 歳が多く，この年龃 層では女性が多かったが，逆に 40 歳以下では男性が多 く，男性対女性の比は 23:29 であつた。

発生時期 : 腹部症状出現は必ずしも夏期に多いとは云 えない。

既往症および患者の栄養状態を示した患者は 12 例い たが，特に貧血やビタミン $\mathrm{B}_{12}$ 欠乏所見は認められなか つた。不定の長い胃晹症状を有した者が 10 例あつた。 又結核の既往を有する者あるい治療中であつた者 6 例，腸管手術の既往を有する者 6 例であつた。

腹部症状の 発現と神経症状発現との間隔は 20 30日 が大多数で，殆んど同時に出現した者 1 例，又 1 例では 約 4 年間の間隔があつた。この様に腹部症状から神経症 状までの間隔は一定でないが，神経症状が出現する場合 はシビレ感が足底部，足尖部に出現し，2・3日の間に 上昇し，臍の高さまで上昇し，固定する事が多い：この 時期に上肢特に手指先にシビレ感を一過性に訴える例一 殷にシビレ感が固定するとそのレベル以下の知覚障害が 現れ，又運動障害がそれに続く：

知覚障害：深部知営として振動覚低下を示した者 12 例, 位置覚低下 10 例, 触営低下 18 例, 痛覚低下 7 例, 痛覚過敏 24 例， vasomotor の傷害を 6 例に認めた。下 肢の自喾的知賞異常は 48 例に認めるが, この知覚異常 が特有であり治療に抵抗するのが特徴である。

腱反射: 腹壁反射消失 20 例, 滕蓋腱反射元進 39 例, 逆に消失減弱は 6 例, アキレス腱反射六進 9 例, 消失減 弱は 28 例であつた.

痛的反射：ワルテンベルグを 12 例，バビンスキー反 射を 17 例に認めた。

脸神経障害: ランドッ一麻痺を 3 例経験したが，1例 はそれにより死しした。視神経障害は 7 例に認められ， 4 例は視力を完全に失つた。

膀胱直腸障害：8例に認めたが，全部共一過性であつ た.

総括：本症と考えられる患者の多くはまず不定の下 㾥, 腹痛等の腹部症状を訴え, その出現後しばらくして 神経症状が出現する。神経症状として患者はまず下肢の 先に始まるシビレ感を訴え，それが $2 \sim 3$ 日の内に臍附 近の高さまで上昇し，他覚的知覚障害が認められる．引
きつついて運動障害が現われるが，運動障害は歩行不能 から，全く異常を認めない例まで程度はまちまちであ る. 知覚障害は全例飞認められ下肢の自覚的異常知覚, 触覚低下，媣部知覚低下，痛覚過敏であり，手指の異常 知覚を訴える例むある.滕の腱反射は光進する事が多 く，病的反射むかなりの例に出現する，アキレス腱反射 は低下する例怔多い，錐体外路障害所見は殆んど認めら れない，又視神経障害を起す例むある。

\section{2. 診断と疫学}

$$
\begin{gathered}
\text { 国立夦病院 内科 } \\
\text { 大 村 一 郎 }
\end{gathered}
$$

1. 與病院を訪れたスモン患者の概況

本症が我が国に見られるようになつたのは昭和 34 年 頃からと推定され 36 年頃から 全国で相次いで報告され ています。與病院ではこれよりかなり遅れ昭和 38 年 8 月に第 1 例が発見され，その後 35 年，37 年発症の患者 が後に1名ゔつ来院している。しかし具で本症が多発し 始めたのは昭和 38 年以後で昭和 41 年をピークとして合 計 129 名である。 その年齢性別は 30 歳代以下では男女 半数で 40 歳以後では男女比は $24: 56$ で女が倍以上であ る。この他に疑い例あるい注不全型ともいうべき症例が 43ある。この疑い例について後述するがこのような 症例は著い世代比多、，恐らく高齢者では疑いとか不全 型に止まらず神経症状を顕わしてしまうと考えた。確診 例につき既往病歴を見ると 53 例 61 回に腹部手術の既往 があり，虫垂切除 $26 ，$ 婦人科系手術 17 が目につく，内 科的既往としては結核 12 赤痢 7 が多い。初発症状は下 痢 69 ，腹痛 $43 ，$ が多く見られる腹部の初発症状として は下肢の異常知覚, 特にしびれ感を以て初発するものが 多い.この下痢, 腹痛などの腹部症状が始つてから神経 症状が始るまでの期間は 2 カ月以内のものが 71 と多、 が 1 年以上の長期も腹部症状の続くものも 24 交る.この 腹部症状，神経症状の始をる季節は不定であるが春夏が やや多い，患者の示す神経症状は深部反射として滕反射 は穴進が 80 で最も多くアキレス反射は消失が 54 で最も 多い、バビンスキー，チャドック等の病的反射は 35 に 認められ, 乳頭の浮腫, 周囲の浮腫, 乳頭発赤, 耳側荟 白などの視神経の異常を訴えるものは 71 例もある。し びれを主とする異常知覚の高さ注以上が 27 腰以下が 91 である。

\section{2. 振動覚について}

また本症では深部知覚を犯されることが多いので，そ の1つ下肢の振動覚を検討した，振動覚は脛骨縁上でC 音叉を用い振動覚の持続時閒を求めた。スモン確診例 
では高度障害の 0 "が 7 , 中等度障害の $1 \sim 4 "$ が 44 , 軽度障害の $5 \sim 77^{\prime \prime}$ が 75,8 以上の正常は 15 で 123 例中 108 例に何らかの障害が認められた. 疑い例では 42 例中 36 例に異常が認められた。次にこの患者の分布注 特別に多発した地域は後述する赤痢後スモンの大崎島を 除けばないが一般に旧呉市内よりも郡部や島および只市 の周辺に多く見られる。

すなわら旧與市内 $47(24)$ （）注疑々症例, 阿賀 13(2) 広 15 （5）黑瀬 4 , 江田島 5 , 㞑橋島 6（1）大崎島 7

(1) 蒲刈島 2（2）が主な所である。

3 . 症例

第1例 50 歳含 会社員 昭和 40 年頃から下永, 時に 腹痛，加療するも軽快せすき，昭 41，1，中旬スモンを疑 う. PSR, ASR 共立進, 下肢振動覚 (以後「振」と略 す）は 7 秒，2月にPSR 九進 ASR 減弱，下浰はやや 軽快「振」は 6 秒, その頃から足蹠のしびれ, 漸次上行 し「振」は 4 秒に低下した。

第 2 例 35 歳含 会社員昭. 40 始加ら苦にならない程

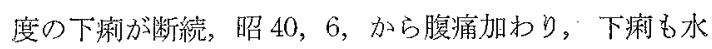
样便が続いた. この時 PSR, ASR とも正常「振」は 9 秒その後 PSR, ASR とも消失 「振」は 7 秒，7月始か ら下肢全般にしびれ「振」は 4 秒に低下した。その後 1 時軽快し「振」も10秒淺復したが昭41，2，から再び 市㻳，「振」は6秒に低下し，下肢のしびれも再び増強 し遂には 4 秒に低下 PSR 元進した.

第 3 例 29 歳古 社会員 昭 40,8 , 加 万下痢 PSR, ASR 正常, 「振」沙 10 秒, 1 週後 RSR, ASR 共圥進 「振」は 6 秒，更に 4 秒に低下した。その頃下痢止まり 下肢のしびれ出現，腰に迄及んだが，間もなく恢復 2 カ 月後「振」は 11 秒に恢復，しびれも消失した。このよ うに腹部症状の時期から続いて観察し得た症例が 59 あ りこのらち後に神経症状が発現しスモン確実となつたも のは 29 女る。他の 30 例は自覚神経症状を顕わさず振動 覚が低下したが腱反射に異常が認められたものでこれら が上述のスモン疑い例，あるいは不全型と考えた。この スモン確実の 29 例について検討すると自覚神経症状よ り先に下肢振動覚低下が見られたものが男 16 女 5 の合 計 21 て下肢振動覚低下があとがたは同時に来たもの が 4 例, 振動覚低下が遂に来なかつた ものが 2 例であ る。このことから 29 例中 21 例は下肢振動賞の低下が自 覚神経痘状の発現より早く来ている，また腹部症状の時 期に腱反射圥進を見たものは20，消失は 6 ，で 29 例中 26 例に反射異常が認められた。これらの事から，下肢 振動覚及び腱反射を注意して観察すると腹部症状の時期 にかなり本症を予知できると思う。

4.エコー 21 型ウイルスとの関連
久留米大学微生物学教室により测定された鈁病院スモ ン患者のエコー21型ウイルスに対する補体要求性抗体価 は 73 例 113 検体の測定で 94 検体が $128 \times$ 以上であり， 腹部症状発現後 50力月が最も高い值を示している。次に 末だ神経症状の発現しない腹部症状の時期に抗体価を測 定し得て後にスモン確実となつた症例を紹介する。第 1 例は 42 歳今の消防夫, 昭 40.11. 加腹痛, 昭 40.12 , PSR, ASR “共元進「振」は 8 " 昭 40.4 .22 , 中和抗体価 $96 \times$, 補体要求性抗体価 $518 \times$ (以後「中価」及「補価」) 昭 41.5. 「振」は 3 秒それと共に下肢のしびれ出現，そ の直後に「中価」 $6 \times$ 「補価」 $1536 \times$ であつた，その後 しびれ，「振」も好転半年後 12 月 25 日には「中価」 $8 \times$ 「補価」 $8 \times$ と低下しております.

第 2 例 20 歳只 当院看護学生, 昭 41.4 方腹痛, 下峲が始まる.PSR 亢進 ASR 正常, 「振」11秒, 昭 41.6 , 「振」 7 秒， 8 月から四肢倦意，昭 41.9.27「中 洒」 $64 \times$ 「補洒」 $768 \times ， 9$ 月中旬加ら下肢のしびれ， 続いて上肢のしびれ出現「振」は 4 秒，昭 41.12.23，

「中価」 $64 \times$ ，補価 $768 \times$ 以上となり現在なおしびれが 続いている。

第 3 例 29 歳早事務員これも腹部症の時期に「振」 5 秒，PSR 元進，「中価」 $256 \times$, 「補伵」 $768 \times$ であつ た。このように自覚神経症状のめらわれない腹部症状の 時期に測定已得た抗体洒を見ると何れも高值である。方 こでしびれなど自覚神経症状はないが頑固な腹部症状と 振動覚低下または腱反射異常があるスモン疑い患者の血 清抗体価を見ると大部分の症例で抗体価は高い価をとつ ていた。

\section{5. 腹部症状の検討}

本症の経過中病期を問わずに影響した消化管レ線像を 見ると器質的異常を示すものは 35 例中 29 例に Hypertonie の像が認められた. 圊で㹥に Hypertonie の像 を示すものはなく Hypo また任 Normotonie の像を示 し小腸とは著るしい対しようをなしている。すなわち小 腸のバリユーム通過時間が極めて早く, 腸管径の大小が ありバリコームが胃がら回忘部まで途切れず連続して いた。これは小腸支配の自律神経異常ではないかと考え る。

始に述べたスモンの腹部症状の時期における腱反射異 常，下肢の振動覚低下，小腸領域の自律神経異常を思わ せるHypertonie の像, エコー21型ウイルスに対する抗 体価の高值などから考え, この頑固な下痢, 腹痛を主と する腹部症状浪にスモンの部分症状であり，しかも神 経症状の 1 分症ではないかと考えなした。

6. 赤痢後に見られた集団発生例

昭和 40 年 10 月, 瀬戸内海, 大崎島, 寸なわち広島県 
豊田郡豊町に Flexnerie に上る集団赤痢が発生 26 名の 患者こ 86 名の健康保菌者が出た。このらち赤痢㭧者 26 名 结本土の県立病院一隔離され，86名の健康保菌者は島内 の学校一収容された：この赤痢患者 26 名のうち 5 名が 赤痢加療中に相次いで下肢の不全痳痺，しびれを主とす る知覚異常が出現しスモンと診断された。発症者の赤痱 治療薬戍に一定の傾问なく薬剤によるものと法考光られ ない. 赤剜菌性 $\mathrm{B}_{2}$ であるる。健康保菌者 86 名加らのスモ 二発症は気づかれていない，このことからスモンと赤㾥 に何らかの関係がある为どうかを見るため; 昭和 36 年 から 41 年に国立舆病院伝染病棟に入院した 15 歳以上の 赤湔患者全員に退院後の様子を問う葉書を発送した. 質 問事項忙「(亻)退院後足が非常にだるか⿰力た，(可足がし びれたか，(視力が落ちたか，(二非常に称汗が出たか，

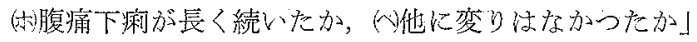
である, 回收率注 $42 \%$ で 231 通の回答があった。 回答 に何ら汃の異常を記載したのは 66 名でそのうち詳細な 症状を附記し，腹痛下痢が続き，下肢のしびれを訴えた 回答が 10 名ありこれはスモンではないかと想像した。 このらち5名が来院しスモン確実または, 極好て疑い濃 厚と診断した。書面によるスモン疑いの10名は回答者に 対し $4.2 \%$ で大崎島の 112 名中 5 名と略及同率である.

書面によるスモン疑い10名の赤刘の状態は症状決定 6 , 健康保菌者 4 で菌型は何れもBである.

赤痢後に Polyneuritis の見ら北ることは Herrlich が 277 例の赤痢で 32 例の Neuritis または Polyneuritis が 合併したと報告して扔り，国内でも赤痱後あるいは粘血 便のあとにスモンが発生したという報告もかなりあり本 症解決に何らかのヒントを与えてくれるか子ししはない。

7. むすび

呉病院で昭和 41 年をピークとして合計 129 名のスモン を診断し得庆. 他の疑い症例が 43 名㚣る。この疑い症例 というのは頑固な腹痛下痢が続き下肢振動覚の低下また は下肢腱反射の異常がありながら自党神経症状のない症 例である、新宮助教授により測定された当院スモン患者 血清のエコー21型ウイルスに対する補体要求性抗体価梳 73 例 113 検体の測定中 94 検体が $128 \times$ 以上である。 た疑い症例の抗体洒は 30 例中 21 例が $96 \times$ 以上である。 小腸のレ線像を見ると 35 例中 29 例に Hypertonie の 像が見ら机小腸領域支配の自律神経異常を想像させられ た. スモン患者の下肢振動覚を見ると 123 例中 108 例に 異常がみられ, 腹部症状の時期からひきつづき観察し得 た症例では自覚神経症状のあらわれる前に多くの症例で 振動覚低下の起ることがわかつた，また腱反射もその時 期に既に異常の来る例が多い。したがつて腹部症状の時 期に注意深く下肢振動覚, 腱反射を観察するならば本症
の早期診断に役立たせることができる，広島県豊田郡豊 町（大崎島）に集団赤痢が発生し26名の赤痢患者から 5 名のスモンが発症した。健康保菌者 86 名からは スモン 発症がない，国立呉病院伝染病棟に昭和 36 年から 41 年 の間に入院した 15 歳以上の赤痢患者に 退院後の様子を 間い, 回収率 $42 \% 231$ 通の回答があり，そのうち 10 名は スモンを疑はしめられた，赫痢しの関連はな梌検討を要 する。

\section{3. 病 理}

\section{九大神経内科}

$$
\text { 三出暂司 }
$$

\section{1.はじめに}

下痢，腹痛などの腹部症状を伴う Neuromyelopathy については，すでに多くの報告がもり，第61 回日本内 科学会総会のシンポジウムにもとり西げられ，本疾患群 は一つの疾患単位ではなくしろ症候群であると云う考 え方と, 本病患群を臨床・病理学的な面加ら一つ疾患 単位であると云ら考えとに分れている，その後も第 6 回 日本臨床神経学会でも.議諭され，その原因を交きらかに 寸るために厚生省班研究班も作られたが，まだその結論 はえられていない。

本症と考えられる Neuromyelopathy の臨床的特徵に ついては，報告者により若干の差異を認めるが，大方の 臨床症状に㜿ける特徴は一致している。私どもが报つた 症例の䠦床像について簡単にのべると，

1) 前駆症状として下䈤, 腹痛などの腹部症状を伴 5 .

2) 神経症状は急性または亜急性に発病する。

3）下肢和端の上行性知覚異常とくにジンジン感には ビまることが多い。

4 ) 知覚障害のレベルは $D_{10} \sim L_{1}$ に多い.

5 ) 知覚障害は比較的深部知覚が障害され易い。

6 ）膝反射はえ進し，アキレス反射は滅弱または消失 する。

7 ) 末梢血液, 髓液に異常を認力ない。 などでその他，直腸膀胱障害や視力障害などを認め，ほ ぽ共通の臨床的特徵を有してている。

この症候群の生命に対する予後は比較的良く, 現在ま での剖検例の報告は少ない, 椿, 高崎, 黒岩, 松山らに より20例ちかくの報告がなされているにすぎず，今回 は私どもが経験した症例を中心に，椿，豊倉教授の御好 意により拝見させていただいた釗路の伊東先生の剖検例 について若干の知見をのべる。 


\section{2. 症 例}

第 1 例は，53 紫の主婦で 37 年 9 月下何，下猁腹痛と ともにジン麻疹様の発疹, 発熱を来たし, 3 週後より淠 下肢のシビレ感上四肢の筋力低下゙を来たし，その後】週 間で歩行困難となる，入院時所見で注四肢の筋力低下著 明，寝返りもできない，視神経領域には異常なく䫓部に も異掌索認めない，上肢の深部反射晠退し，下肢では 膝反射注六進し，アキレス反射は消失している，両側性 にバビンスキーが陽性で，知覚障害は第10胸髄以下に 全知覚の低下夌認める。11月中頃より諸症状は漸次軽快 し，38年 1 月に注步行与可能となる。2月になつて再び 下肢のジンジシ感安訴え，歩行困難亡なり，4月初，下

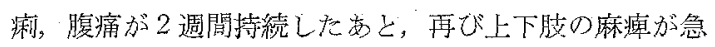
速に進行し，言語障害などもきたし死亡した。剖検所見 では，春髄は頸䯣で後索の変性が著明であり，主として

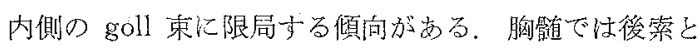
側索部にほぼ雨側性に变性を認め，下部胸䯣で注後索よ りも側荣の変性が主となり, 脊髄の変性は上行するに従 つてその程度を強め, 頸䯣では goll 束に, 胸髄では

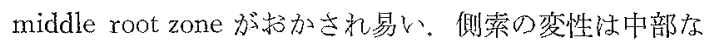
いし，下部臉髄の高さょり以下にみられ，これは後索の 変性と丁度逆となり下行するにつれて著明となり, 頸髄

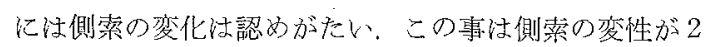
次変性ではなく, 原発性のものではないかと考えられる。 本例の頸髄の goll 束はほとんど完全に脱髄し，䯣鞘の 腫脹，断裂，崩壤を認的古。変性の著明なとこる活軸索 も変性し，腫脹，断裂などの変性も認める。

脂肪染色では変性部位に一致して多数の脂肪顆粒細胞 が出現している。

神経細胞の変化は少ないが，病変の著明な部位の前角 細胞はややその数が減少し, 細胞の萎縮, 核の偏在など を認める。委た軸索が著明に膨化し，axonal reaction の像も認められる。 Horzer 染色では変性部位にグリア の増殖, gliosis 吕認められる。

资髄実質に㳉全体にグリアの増殖があり，血管周国の 細胞浸潤は認めない.

meningen 後桹の血管周囲にも炎症性細胞浸潤ほ認め ない，報告例によつて注管周囲の細胞漫潤吕認められ ているが，それは整度なものであり，炎症性反応を少る ことは稀である。脊髄神経節では神経節細胞の萎縮, 変 性，消失が認められる。しかしながら春髄レベルにおけ る神経線維の消失に比べると，その変化注明らかに軽 ᄂ.

末梢神経では脊髄根神経, 韮腹神経で髄鞘のびまん性,

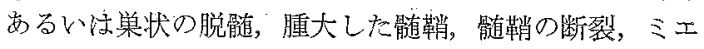
リン球などが認められる。一方軸索の変化は軽度であり
細胞浸潤なども認めない.

われわれの症例では視神経に洪常なく, 症例によつ ては視神経の脱䯣変性が報告されている，椿，豊倉ら は，主として球後より視神経交叉部から外側膘状体にお よぶびまん性の脱髄変性とくに中心部の神経線維がかが され，その部位に一致してグリア細胞の増殖と多数の脂 肪顆粓細胞が認められた例を報告していた。

また，椿，豊倉らによつて報告された釧路の剖検例は

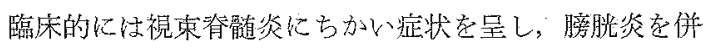
発し死亡している。病理所見で最も病変の強い部位は下 部胸髄より上部腰䯣にかけた高さで対称性に後索拉よび

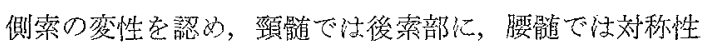
に側索が変性し，われわ机の症例とほぼ類似の所見が認 められる。

われわれの症例また他の報告例より病理組織学的な特 徴注,

登髄では長神経索部すなわち, 後索と側索の変性であ り，後索の変性は上部頸䯣に著明で，かつ内側の goll 束に強々傾向がある。側索の変性は下部胸髄に著明で， 後索で朔に下行寸るに従つて明瞭となり，末稍神経末 よび視神経にも，時にび李儿性，支るいは栄状の脱髄が 認められる。朝索も膨化，変性などを認めるか，髄鞘の 崩壊に比べると，はるかに軽いと云つた病理所晃を蓑げ ることができる。

しかしながら第2 例の臨床像は，35年11月下痢，腹 痛をきたし，4〜5日持続し，大腸炎と診断される治療 老受け，約 10 日後より右下肢の知覚異常をきたし：シ ビレ感恃上昇し，心窩部安でおよび，歩行も困難とな る。治療により約 2 力月後には歩行可能亡なつたが， 36 年 3 月再び下痢が数日間続き右上下肢の不全麻痺をきた している，5月に婳気，湢吐などの胃腸症状後，下肢は 完全麻缯となり，9月に又一人立ちできる位回復してい る。10月に再び四肢麻瘏が著明となり，膀胼炎を併発し 全身状態の悪化を来たし，発病 1 年 3 力月で死亡してい る。

病理所見では大脳，小脸に注変化なく，延䯣の錐体に

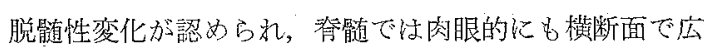
汎な変化があり, 頸髄では後索, 側索また前索にも脱骴 性の病変を認め, 第 4 胸髄では主に側索に，下位胸髄で は側索に比較的限局した脱髄性变性を認め, 病変は pla queをなしてみられ，脱骼栄に一致してグリアの増殖が 認められる。血管周囲の炎症性変化忙之しい。

本例は神経症状発病前に著明な下浰, 腹痛などの腹部 症状があり，その経過中，神経症状の増恶する前に，腹 部症状を伴つている. 病理学的にも筲髄で法後と側索 を主とした脱髄変性であり，本症候群に類似しているが 
われわれ㹥多発性硬化症に近い病変だと考えた。また次 の症例も下㾥，腹痛をきたし，瓷便中に赫痢菌が証明さ れ，その後続いて四肢の知覚障害と運動障害さらに視力 障害をむ伴い，病理学的にも本症候群と類似した所見を

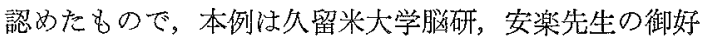
意により捧見させていただいたものである。

臨床経過注，33年 9 月，下疮，腹痛をきたし翼便中に 赤瘌菌が証明され，治療により一時軽快したが，10月に なつて再び下痢, 腹痛, 発熱を来たし, その頃より下肢 の上行性知覚異常を共に四肢の筋力低下，さらに注意識 む傾眠状態となる。その後視力も低下し，全身状態の悪 化と，膀腅炎を併発し死亡した例である。

病理所見は，脊䯣は上部胸髄では左右対称性に脱䯣し 後索は主に goll 束に著明で, Burdach 束にもおよんで マる，側索も対称性に脱髄変性を認める。頸髓では後索 の goll 束の変性が主である。腰檤でも後索, 側索に軽 度の変性を認める。

脂肪染色で病変部に一致して脂肪顆粒細胞を認める。 視束では視束交叉部を中心にまた球後から外側膝状体 化か訬て変性が認められる。

\section{3. 考察}

以上 3 例のうち第 1 例はいわ妕る本症候群之考光られ る症例であり，第２例法多発性硬化症に近いむのと思わ れる. 第 3 例も赤割のあとにみられたものであり，いず れも類似した所見を示している。すすなわち本症候群と考 えられるものの中には，いるいろ類似の疾患が含まれる 可能性があり，臨床的にみても，腹部症状を伴うものに 恃, Polio, Guillain Rarré などの感染症をはじめ, 代謝 执よび栄養障害によると考えられる瑟性貧血，糖尿病，

Amyloidosis にも認められる. また最近外国で問題にな つている Coeliac disease でも腹部症状を伴つた類似の 神経症状などが報告されている，その他中毒による場合 や，多発性硬化症，視束脊䯣炎などの脱髄疾患にも認め られることはよく知られている。

病理学的所見からみると, 本症候群の特徴注長神経索 の索変性であり，炎症性変化仁乏しく，系統的変性疾 患, 中毒，代謝障害にみられる病理像に類似したものと 考えられる. なかでも悪性貧血にみられる亜急性連合性

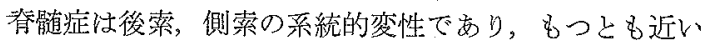
病理像だと云える。しかし本症候群には末梢血液に異常 がないことなどよりこの可能性は否定される。

末梢神経に脱䯣変性を認めることなどから，Guillain Parré も疑われるが，䯣液に異常がないことなどから， これるいわゆる Guillain Barré 症候群の中に注いらな いものと考える。

病理組織学所見は炎症所見がほとんどなく，後索や錐
体路の様な長索路を形成するもののうちで，とくに長い Neuron が招かされ易く，しかも末端加ら変性が序々に 神経細胞体に及んでいくと云った印象を受故る。

なお本症候群に類似した臨床像および病理像を示寸神 経系の感染症はまだ報告がなく，本症候群がウイルスあ るいは他の感染によるものとすれば，神経細胞よりも索 性の変性が主であると云つた unusual な型だと考えられ る.

\section{4. 総 括}

1）本症と考えられる剖検例による病理学的な検索で は，炎症所見注少なく，脱髄変性が主である。

2 ）脊䯣の変性注系統的変性疾患，中毒あるいは代謝 障害を疑わせる様な長神経系すなわち後索および側索の 索変性であり，末梢神経にも变性を認めるが，䯣鞘の崩 壞に比して軸索の変化法軽い。

3） 3 例の症例でも示した様に，各疾患が中には本症 候群と類似の症状を呈するものが多く，今後は本症候群 と考えられる症例の臨床病理学的な面からの検討が必要 であり，剖検例による，神経各部位のくわしい険索の他 に消化管などの祫荤を必要とするものと考える。

\section{4. 病因}

久留米大学医学部微生物学教室 新宮正 久

本疾患の病因については，多くの先人の努力にもかか わらず，従来不明であるとされてきた，ただ甲野礼作博 士 (予研) は Gojdusek の創見である slow virus infections の一種ではないかという作業仮説を示したが，し かしこの具体的な根拋は述べられていない。

私注次に述べる様な事実から，本疾患の病原として ECHO 21 型ウイルスを，発病機序としては ECHO 21 型ウイルス粒子そのもの, 又はその増殖によつて産生さ れる物質による遅延型アレルギー反応が特定の脳脊髄組 織で起つているものと考えたい。

(1)，疫学的事実から本症が感染性のものであること は可なり確実になつたものと考える。

（2） 1965 年福岡県下浮羽町と八女市に捛讨る患者よ り初代人胎児腎細胞を用いて糞便より 5 株, 脊䯕液上り 2 株，全血液より 1 株の ECHO 21 型ウイルスを分離し た.

（3）ECHO 21 型ウイルスは初代人由来の細胞での み增殖し細胞変性を示し, 猿腎細胞では細胞変性を示さ ない特殊な唯一の $\mathrm{ECHO}$ ウイルスである。

（4）分離ウイルスはいずれも prototype Farina 株 と免疫学的性状は全く同様の性誓を示したが，動物血清 中の inhibitor に非常に感受性が高いといら点と組織培 
養細胞に掞斿る增殖が遅いという点で Fanina 株とは区 別しうる。少くとも分離操作中の Farina 株の污染法否 定しうる成績である。

（5）本疾患流行地（釧路, 空蘭, 哭), 非流行地 (防 附, 山口, 門司, 久留米, 大村, 宮崎, 日南）の正常血 清 1800 例の抗体保育状洗堂調查したが，本疾患の流行 地注 ECHO21 型ウイルスの高度の浸澄を示していた。

（6）全国各地の 240 症例（血清数 345）について 血 清学的検萗を加えたが，患者血清の，ECHO 21 型ウイ ルスに対する中和抗体価注神経症状発現時がもつとも高 く, 次第に低下し，30日以後の血清の抗体価は低くな る. 2 メルカプトエタノール处理法及び DEAE セルロ 一ズカラム分画法によれば，この高い抗体は IgM であ り，IgG 病期を通じて全く変らず～16 倍程度を維 持している。一方，正常人血清 ECHO 21 型ウイルス髄 膜炎患者血清, あるいは動物に免疫して作つた抗血清の 抗体は IgG が大部分を占め IgM 注極めて少い。すな わち本疾患の場合，一般のウイルス感染症とは異り， IgG 汇動かず，IgM のみ上昇するという特異な抗体産 生像を示す，こ机怔少くとも初感染により発病するウイ ルス感染症とは考允られな。

（7）本疾患の患者血清の ECHO 21 型ウイルスに対 する補体要求性中和抗体価注，神経症状発現上りかなり 期日を経たものでも普通の中和抗体価の 10 倍以上も高 く，これは本疾患の血清学的診断に役立てることができ る。この補体要求性中和抗体泣 IgA 分画に含まれてい る.

（8）ECHO 21型ウイルスに Freunds complete type adjuvant を添加しモルモットの皮下接種することにより 10 20日後飞約 50\% の割で後肢麻痺を起し整すことが できる。この際の発生モルモットの血清注本症患者血清 と同様に $\operatorname{IgA}$ が高く, $\operatorname{IgG}$ は低く, 生残モルモットの 血清は IgG が比較的高いのが常である。勿諭, ECHO 21型ウイルスのみ，adjuvant のみの接種では発症させ ることはできなかった。この抗原と, complete type adjuvant の併用注実験的アレルギー性疾患を作りうる方 法としてはしばしば用いられる手段である。

（9）1966 年 7月上り 10 月にかけて釗路；室闌，東 京, 與の患者より ECHO 21 型ウイルスを 6 株分離しえ た。（リコール2 株/14検体，糞便 4 株/29検体）

（10）DEAE chromatographyにより患者血清を分画 するとポリオウイルス・ヘルペスウイルス・ECHO6 型 ウイルス・インフルエンザウイルス等に対する抗体は $\mathrm{IgG}$ 分画に存在するが $\mathrm{ECHO} 21$ 型ウイルスに詨する抗 体注 IgM 分画に大部分が存在与尚。な補体要求性抗 体注 $\operatorname{IgA}$ 分画侾在する。一方，正常人の $\mathrm{ECHO} 21$
型ウイルスに対する抗体は IgG 分画に存在する。

(11) ECHO 21 型ウイルスと Freunds complete type adjuvant と专少ルに接種して穴た抗体は IgG 分画より IgM 分画に多く対照に用いたポリオ 2 型, ECHO 11, ECHO 12 等では IgGにほとんどの抗体が存在する. 又 $\mathrm{ECHO} 21$ 型ウイルスに效する補体要求性抗体注IgA 分画湽々とめられた。

（15） SMON 発病 33 発病で死亡した患者の大脳打よ び脊㩆抽出液より ECHO 21 型ウイルスに対する中和抗 体と高い補体要求性中和抗体を証明することができた。 この抗体の免疫学的同定沬未了であるが, ポリオウイル スやへルペスウイルスに対しては中和を示さないことか ら ECHO 21 型ウイルスに效する特異的抗体と考党られ る.

\section{主要文献}

1）新宮正久他：腹部症状に続発する瓷剈炎の病原に 関す古研究，日本伝染病学会猚誌，39:139-144, 1965 -2) 新宫正久：腹部症状に続発する䠲䯙炎の発病譏 に関寸る研究，日本伝染病学会雑誌，39，442-449, 1966. - - 3) 新宫正久: 腹部症状に続発する脊哊炎症 の近年增加に対吉る疫学的考察, 日本伝染病学会雑誌 40，247-250，1966，一-4）新宮正久他：腹部症状に続 発す当答髄炎の血清疫学, 日本伝染病学会雑誌, 40 , 454-459，1967. 一-5) シンポジウム腹部症状を伴な 与脳脊䯑做炎症，日本臨床，25，180-206，1967.

\section{特別講演}

\section{呼吸器ウイルス感染症}

一特にライノウイルスを中心々して一

岩手医科大学医学部細菌学教室 川名林治

1.はじめに

呼吸器ウイルス感染症の問題は, その病原ウイルスの 研究は勿論, 疫学, 臨床医学の面などからも，極めて重 要な課題であると思う。

従来，臨床を中心とした精細な研究がインフルエンザ などについて行なわれてきたが，過去十数年間における ウイルス学領域における種々の学問技術の進歩に伴い， 多数のウイルスが分離同定され，病因としての意義が次 第に解明されつつある。

組織培養法のウイルス学への導入により，1953年 Adenovirus が分離され，ついで Parainfluenzavirus， Respiratory syncytialvirus などが次々と分離され，ま た多くの Enterovirusなどが分離されるとか，一方では Mycoplasma pneumoniae の培養の成功, ついで Rhinovirus が登場するに友んでいる，多くの研究者の努力に 
よってこれらのウイルスの性状，病原性などが漸次明ら 加となってきた， 专た本邦の多くの先喾によって幾多の 知見がこの間報告されてきた。

最近では蹦床上の重要なウイルスについてのワクチン の開発研究も旺んとなり，その效果も確認されつつあ り，一方で仿いくつかの抗りイルス剂についての研究も 進めら机ている。

わたしは，呼吸器ウイルス感染症の問題について概説 するとともに，るたしたらの，ささや加な研究を加完， さらにライノウイルスについての問題などについて述べ たマと思う。

2. 蹊床少イルス学的なとがら

呼吸器ウイル久感染症索起すウイルスとして現在知ら れているものとしては, Influenzavirus A, A1, A2， B, C., Parainfluenzavirus 1, 2, 3, 4, Adenovirus 1 33, Picornavirus として Enterovirus (Coxsackievirus A, B の两群と，そ扎ぞれ1〜24，I～6の亜型，Echovirus $1 \sim 33$, Poliovirus $1,2,3)$ 站よびRhinovirus $(55$ 型以上）などが代表的なもので，この他従来ウイルスと 考えられてマた Mycoplasma などが要げら就る。

これらのウイルスによってひき起される疾患は, 重症 な肺炎，毛細気管支炎加ら，気管支炎，咽頭炎，鼻炎， さらには無症状のものまでさまざまである。しかて，精 細な症状の分析により，現在例え枝乳奻児の重症な下部 気道疾患注として Respiratory syncytialvirus による ものか，次いで Parainfluenzavirusによるものが多いこ

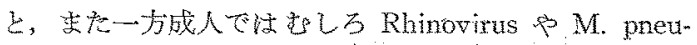
moniaeなどによるものが多いことなどが判明してきた． また同じウイルスでも極めて多彩な病像家示すこと（例 えば Adenovirusや, Enterovirus 度どように) 再感染 をくりかえすことが血清疫学的に明瞭になつ炕の（例 Respiratory syncytialvirus のように)，などもある。

従来, 呼吸器ウイルス的分離恃困難なものをされ, 血 清診断さ完客でなかったが，現在 Hilleman, Chanock 招よび Parrott ら，㐫るい柱英国のかぜ研究グループの

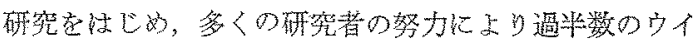
ルスの分離ないしは血清診断が可能になったことは極め てよろこばしい，宋た個々のウイルスにより特徴的な病 像分析もか子孙可能になってきた。ささらこ机に細菌や Mycoplasma その他の微生物の追求亡か，現在注目され 注じぬた器官培養などの応用により近い将来，ほとんど すべての病原分析が可能になることを期待し，努力した いものである。

\section{3. 実験案診断法}

臨床診断によつてウイルス性であることを推定するた 为, 臨床像, 血液像, 発疹, ウイルス以外の微生物の否
定，化学㙩法の效果の点などから考察が加えられ，いく つかのウイルス性疾患（麻疹，風疹など）で注，注ぼめ やまりなく診断が下されるものも㐫るが，多くのウイル 又性疾患の場合, とくに呼吸器尚イル久感染症の場合注, 実験室診断との綜合協力なくしては不可能であるといる よう。

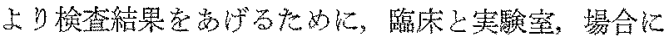
よっては疫学者, 行政官症ど, との密接尔連絡をたも

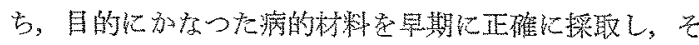
の保存輸送に細心な注意索払い，またできるだけ，急性 期と恢復期のペア血清を採取寸可，そして確害適切な分

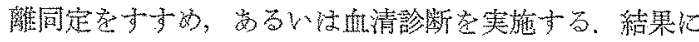

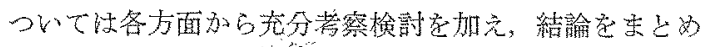
る必要が者る。

わたしをちは，少イルス検查のための学内外方らの传 頼カードを使用し結舆索報告しているが，呼吸器ウイル スについては更に精細な事項を記大するカードを用い， 集計分析に灾用している。

現在，わたしたちは，実駼室診断法としては，病的材

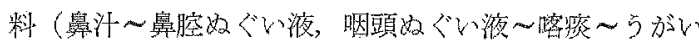
㴶, 賞便, 䯣液その他) $0.5 \%$ Bovine albumin 加 veal infusion broth (Penicillin. Streptomycin などの抗 生物質の入ったものと入らないもの）にとりここ礼から ウイルス分離，細菌や Mycoplasma の分雄をしている。 接種まで日数を要するときは，ドライアイス・アセ卜 ン（又はアルコール）中で急速䡆結し，岀と接種まで一 $70^{\circ} \mathrm{C}$ の Revco など保存している。

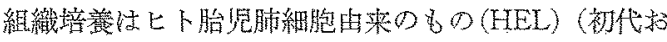
よび継代したもの)，警（HEK，初代）サル謷，HEp2， HeLa，FL その他莸併用し，交た（Coxsackievirus の

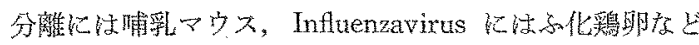
老併用している。分離した agent の同定法ウイルスに より種々である。

血清診断飞法，中和反忘，補体結合反応；赤血球凝集 反応，などを主として周いる。螢光抗体法は実用化され

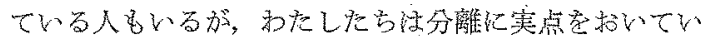
る.

\section{4.わたしたらの三，三の研究}

わたしたち注，1964年以来，少し系統的纪呼吸器少小 ルス感染症について，ウイルス分離を中心として，これ

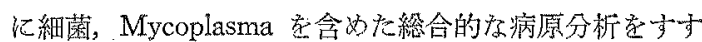
めているが，これまでの成績饥いて，二，三まとめて 为たい。

とくにウイルス分離にヒト胎児肺由来の Diploid 細 胞 (HEL)，およびヒト胎児㹂初代細胞 (HEL) 省主とし て使用した点に意義があると思う。 
实験方法は，患者注盛闻旓むよびその近郊に登生した

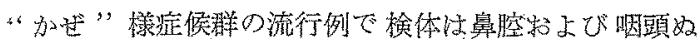
ぐい液その他（時に賽便その他）を用い，前述の方法に よった. ウイルス分離には-HEL 細胞起中心に HEK, HEp2，HeLa、Vero および MK:細胞などを適宜組合せ て使用した。いずれも2\%估牛血清加 Eagle's MEM蛋

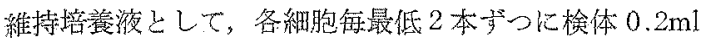
ずつ学接種し $33^{\circ} \mathrm{C}$ で回転培養を行ない，CPE 晾よび 0.4\%モルモット赤血球とよる Hemadsorption 学もつて ウイルス分離の示標とした，同定には Adenovirus

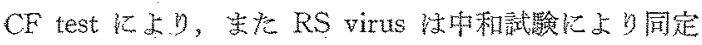
L，Rhinovirus 注 IDUR 感受性試䮦，Ether 陑性試 睮，酸酎性試験，大きさ，中和試験によって同定した。 Enterovirus は以上のウイルス以外のもので，細胞感受 性と CPE の状洗によつて，Enterolike-virus とし，直 清学的（中和）以上つて同定した。

PPLO の分離飞快 Chanock の PPLO broth および agar 索使用し，細菌分離纪は血液寒天杼よび Staphylococcus 110 培坆孛使用した。

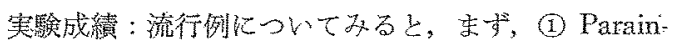
fluenzavirus type 3 kよるすので泳，岩手県川井村小学 校の 4 年生クラスで1966年4月初旬加咳濑表症状 とする急性上気道疾患が多発し，ひきつづいて 2 年, 1 年 さらに绦接の幼程園，中学校にも流行は広がり，小学校

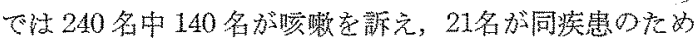
欠席した．流行注タラス単位に発生し，約 4 週間の経過 で終熄した，しかし一般住民の閒で恃学音閐の上らな流

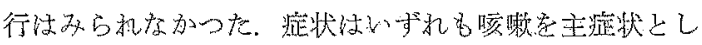
特に夜間に激しいと挀えたが，鼻㳆，喵頭発赤，発熱な

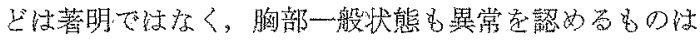
殖んどなく，いずれもや10日間で全治した。

(2)，岩手県北の一开町に和以て星同年4月中旬为占下 旬にか忖(と同様の主症状のものが多発し，5月上旬ピ

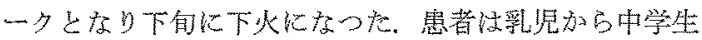

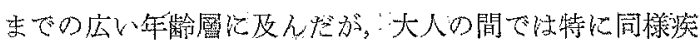
患の流行は認められなった。経過は(1)とはほ同じで治癒 した.

これらの流行でのウイルス分離は，HEL 綎胞を主と し，これに HEp2，Vero 学併用したところ，HEL 細胞 に3日目頃から CPE が現われはじめ，流行例(では15 検体中 2 検体に，宗流行例 (2) では21 検体中 17 检体に

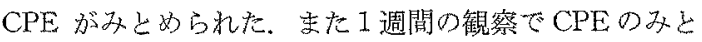

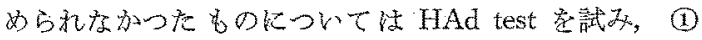
では 14 検体中 11 検体に, (2)では 9 検体中 8 検体に陽性 結果をえた，これらの分離株について HAd-Inhibition test T゙ Parainfluenza type 3 と同定した.
血清学的には HI 抗体密测定した. こ玌により，流行 例(1)では 16 例中に 12 例に，また，流行例(2)では 9 例中 6 例に 4 倍垔たはそれ以上の Parainfluenzavirus type 3 亿対古る HI 抗体の上萃が認方的た。

散発例での分離成績で㤬，小胃例で注 477 例中 194 例

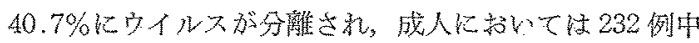
44例，19.0\%にウイルスが分離された，乙の内訳法，小 晃では HAd (十) virus (Parainfluenzavirus 一部末同定) ŁRS virus が多く，成人では Adenovirus が多い.

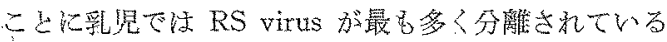
月别飞名を $\mathrm{RS}$ virus $11 \sim 3$ 月住, $\operatorname{HAd}(+)$ virus 洁5月垻まで, Adenovirus, Enterovirus など注冬以外 の季節比をとれている.

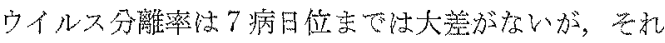

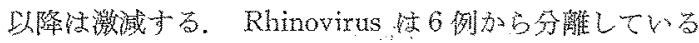
加うち1例は，はじめ“鼻加ぜ”で，後，気管支炎

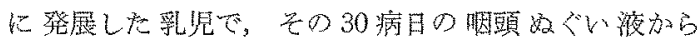
Rhinovirus が分離された興味多る例である。材料别に

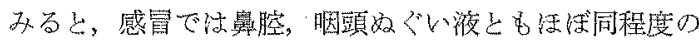
成續で，咽潩炎，気管支炎，肺炎では咽頭好ぐい液で分 離率がよく，ことに肺炎では著明であつた。これはいず れのウけレスで同し傾同老示していた。

分離ウイルスと症状との関係では，いずれのウイルス

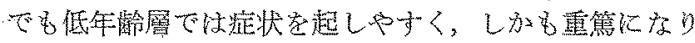
やすいが，Rhinovirus で法各年龄層に括いて咳濑，鼻 汗が著明であつたが，只の他の症状に之しく，6例中 5

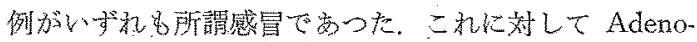
virus 注他のウイルスに比べて年長者に拈いても症状が 重くなり易、傾向を示している，乳纤先の肺资でウイル 大分離のできたものは12例であるが，そのうち7例は RS virus によるもので, RS virus の乳幼児に詨子る重 要性学よく示している.

細菌検查についての意味す汗の点で性，かなりの困難

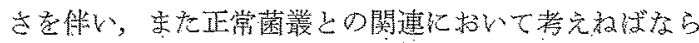
ないと思うが，病原菌として一店考光られるもので菌数

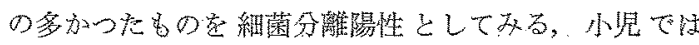
164 例中 36 例，(21.9\%) 飞，成人で 118 例中 14 例加 らで：そのう告 $\beta$-Streptococcus が 50 例中 28 例加ら， 次いで Staphylococcus aureus 17 例, Pneumococcus 5 例であったそそのうらウイルスがともに分離されたもの 注50例中 14 例で嵓つた。

PPLO (Mycoplasma) の検索仿，289 例について実施 したが㓌性であつた。

また，别に.1964年夏，岩手県花巻小学校赏中心として， 最初数名の咽頭結膜熱の鲁者が市つたが，始業(秋の)直 後水泳プールによつて増幅されて，非常に大きな流行を 
みた例に遭遇した，この流行は小学生を中心として流行 し，さらに家庭内で幼児などにもひろがり，また隣接の 小学校などにも波及した。この流行は少くをむ1000名 以上に患者が及んだが，わたしたち注，患者の㸶頭妨ぐ

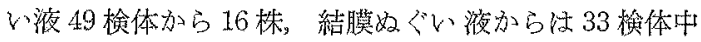
14 株, 糞便 9 検体中加ら 8 株のAdenovirus type 3 を分 離同定した。 またこの際血清学的に CF と HI，NTな と学比較したが，HI 蛙非常に有用であることをみとめ た.

また更に，Adenovirus によるものに，医師の眼科的 検診後に流行性角膜炎の流行を 1962 年飞経験した。 こ

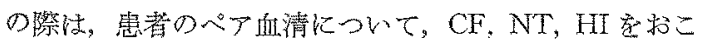
ない Adenovirus tyre 8によるもので交ることを決定 した:

\section{5. ライノウイルスについて}

Rhinovirus は最近数年間の研究で，潮くウイルス学 的に確立してきた。

はじめ Tyrrel] らの英国の Common cold research unitのグループによつて所謂惊なかぜウイルスとして報 告され, (Salisbury strain), その後 Rhinovirus, Murivirus, ERC virus, Enterovirus, Coryzavirus などとよ ばれたが，これは同一のカテゴリーに入るるのとしして さきに分灕された ECHO 28 virus とともに Rhinovirus とよばれることになり (1962)，Enterovirus とともに， Picornavirus に含まれることになった。

Rhinovirus 注 Picornavirus の名の示寸如くRNA 型 の小型 $(15 \sim 30 \mathrm{~m} \mu)$ ウイルスで, $33^{\circ} \mathrm{C}$ の回転培養で, ヒト胎坚由来の Diploid cell culture でよく增殖する. エーテル耐性である，特徽的な性質は酸に対してすみや 加不活化される (pH 3.0)ことで, Enterovirus との 爁別上にむ応用される，H型（ヒトDiploid”cell のみ で增殖する）と，M型（悭細胞でも増殖声る）とに 分汀ら机る。

起す病気沖所謂「はながせ」などの上気道の感染症の 型で来ることが多く，成人から分離される率が多いが， 小児の瑒合法他のウイルス感染に要らわれるため加率は 低いが，症状法成人に比し重症で岁る場合が少くない，

わたしむ NIH の Dr. Chanock の下に㧍いて6 株の 新しいRhinovirus 分離したが，(209，1794，56110， $56822 ， 58750 ， 71560)$ その後も，主として米国执よび 英国において新型の Rhinovirus 加次々に報告されてお る. わたしも日本で初めてと思初光尚 Rhinovirus 2 株にていて分離の報告をすでにしたが，この粎について の堌殖の問題学培諩条件 $\left(33^{\circ} \mathrm{C}, 37^{\circ} \mathrm{C}\right.$, 回転, 静置など) をかえて基礎的仙研究した，現在わしたたち手技とメヂ ウムの改良により興味岁る成績它光つつ岁る。
また HGP と 1794 株の日本に战ける扰体の有無をし らべるため中和抗体をみが，(自衛隊員（一本木）の 1965 年, 1966 年のペア血清について), HGP に対して

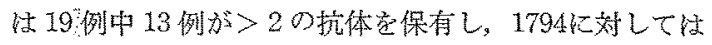
21 例中 10 例が抗体を保有し，さらに雨年の間に多少の 抗体の変動があつた点をみとめた。

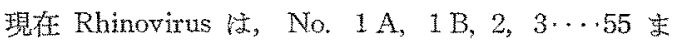
での番号によつて呼称されるように提唱されている。し かし，その後も次々に新し々型が報告され，またOrgan culture の手技の導入などによつて，さらに新しいRhinovirus が報告されていることからも，今後のわたした ちの努力が必要と考える。

\section{6.むむび}

呼吸器ウイルス感染症の閶題について, 多くの先輩の 㛎力によって，わず加10年岀まりの間に，この方面の知

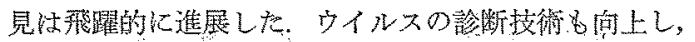
その $40 \sim 80 \%$ 位まで注実験室診断が可能となり, ウイ ルス学の裹付订にたつた臨床, 㾤学なぜる非常な進歩を みた，とくに Organ culture と tissue culture (さらに 英国の volunteer study）の併用などにより，新しいウ イルスの発見が更に希望がもたれるよらになつた。また 古いもの加新しいウイルス泉で, 不断の基礎研究, 病 因諭的な研究が続けられている。特に，ワクチンの開発 が重要な呼吸器ウイルスについてすすめられ，明らかに 有効な結果をえているので, 今後の努力により、より上 いワクチンの生れる希望がでてきたし，亦た抗ウイルス 剂の開発の研究むはじめられてきた.

臨床医学江直結した呼吸器ウイルス研究のしごとは極 めて大切な課題でありながら，その反面，極めて地道な 努力が要求される，また実験室と，臨床医家の密接な努 力が必要で方る。

今後とも内外の諸先輩の御指導をえて微力をつくして いきたい。

\section{シンポジウム III \\ ウイルス病と免湾}

\section{1. 麻 疮}

a. マシン接種効夥について

久留米大学小罗科

船津 維一郎

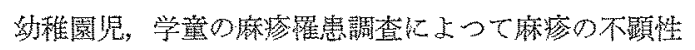
感染沙清学的に推定さるりるのが $6 \%$ に見出された。 この事実は痳疹の不頭性感染に関古る関心を高方る。感 染指標しして CF 抗体の消失定自然扔上び接種麻疹につ 
いて検すると 12 力月後は抗体消失する，然るに免疫疫 学によると CF 抗体の年齢分布は 15 歳以上は $4 \%$ 以下 となるが老年に至るまで証明し得ることは CF 抗体の自 然消失から再感染の機会があることを推定させる，CF 抗体保有率を自然麻疹罹患後 10 年に亘つての調査でも 約 $20 \%$ に陽性で岗り，また接種麻疹後の 3 年後にも同 様のことがみられる，罹患児の母親の不顕性㾁疹例もあ る. 受動免没による乳呪の CF 抗体価加らも母親の不顕 性感染性定される。な叔， $\gamma$-G $\mathrm{G}$ 投与児には $\mathrm{CF}$ 抗体 は上昇せず，また不活性化ワクチン接種では12月後は陰 転する。

以上から自然麻疹後の持続免疫性初感染後におこる不 顕性重感染によつて保持されていると推定され，麻疹口 クチン接種に任重感染に支持される持続性効果が期待さ 机る。

\section{b. 麻疹ワクチンおよび麻疹混合ワクチンの 纪瘠学的検討}

熊本大学医学部小览科学教室

$$
\text { 貴田丈夫 }
$$

最近迄私の教室で行なわれた麻疹ワクチンに関する研 究の一端を披露して御批判なり，御教示を賜わりたい。

I 麻疹ワクチンの遠隔成績および追加接種実験

1962 年より1965年迄に行なわれた麻疹りクチン研究 会の研究成績に基き，現時点で性，不活化・生ワクチン 併用法 (KL 法) により，1966 年より一般に任意接種が 行なわれるようになつた。

しかし乍ら，抗体の持続，追加接種必要の有無・時期 などについて，今後榆討さるべき問題恃多い。

よつて教室では，各種の麻疹ワクチン接種者につい て, 長きは 3 年平, 短きは, 1 年半後の抗体量を追及し た後, 追加接種を行ない, その接種効果および臨床反応 老検討した。

方法・対象 L. KL. KKL. KKK接種者 800 名中 182 名に，L又はKを追加接種した．外に placebo 26 名で， 法伝研 Lot. 7 の生ワクチン $(0.25 \mathrm{ml}, 1$ 回)，Kは

Lot. 1 不活化ワクチン $(0.5 \mathrm{ml}, 1$ 回 $)$ ，抗体注 NT.

HI. CF 抗体を接種前と接種 1 力月後に測定した。

1. 初回接種後 3 年半ないし 1 年半の NT 抗体価 L 㧛 独接種群の幾何平均抗体価任

6 力月後, $8.20,1$ 年後, $8.15,2$ 年後, $7.81,3$ 年 半, 6.92 .

L単独および $\gamma$-gl 併用群では

1 力月後, $8.80,6$ 为月後, $8.34,1$ 年後, $8.39,2$ 年半後, 7.82 .

$\mathrm{KL}$ 群では
1 力月後， $6.85 ， 6$ 力月後， $4.38 ， 1$ 年後, $2.40,1$ 年半後は不顐性感染のためか 4.78

KKL 群で流

1 力月後, $5.99,6$ 力月後, $4.55,1$ 年後, 3.94, 1 年半後不顕性感染のためか 5.35 .

KKK 群では

1 力月後, $4.99,6$ 力月後, $3.94,1$ 年後, $3.55,1$ 年半，不顕性感染のため力 4.45 .

KL，KKL，KKK は同時に行なつた実験群でめり，各 群内でばらつきの巾が広い。

要之，Lのみ又は $\mathrm{L}+\gamma-\mathrm{gl}$ では 1 力月後の NT 抗体 価高く，且，長期高值を持続するが，KL，KKL. KKK では，6力月後の抗体価任低下が著しく追加接種の必要 性を示晙寸る.

2 ・追加接種による発熱者とその抗体洒,

追加接種者の内，発熱者は，L および $\mathrm{KKL}$ 群では $0, \mathrm{KL}$ 群中追加接種 $\mathrm{L}$ で $2 / 32(6.3 \%), \mathrm{K}$ で $1 / 25(4.0$ \%), pl. $1 / 9(11.1 \%)$, KKK 群中Kで 0, L で $3 / 32(9.4$ \%) に外られた。発熱日梳種後 $2 ， 4 ， 8$ 日目で，持 続日数恃 $\mathrm{KL}$ 群で江 $\mathrm{KKK}$ 群より短い。

追加接種発熱者の追加接種前 NT 抗体洒法, KKK群 ではかなり低值であるが，KL 群では低值とはいえない しかしながら追加接種に上る発熱は追加接種 (K. L) の ためとはいえない。

\section{3. 追加接種前後の抗体佰}

追加接種のKなるとLなるとを問わす，追加接種 1 力 月後は NT. HI. CF。の上昇が斥られ，Lの追加接種の 方が優れていた。

又，この上昇は KKK. KKL. KL 群で著しく， L 群 では接種前の低下が少いので追加接種による booster effect 注著明でない，このことも KL 方式に対する追加 接種の必要性を示唆子る。

又 NT 4 倍以上上昇例定追加接種の有効例として有効 率を比較しても，L群の有效率は低く，KL.KKL. KKK 群の方が追加接種の有効率がない。

II. 2-ME 処理血清の麻疹 NT 抗体

2-mercaptoethanol で血清を処理すると, 血清中の Ig M抗体索消失させ，IgG 抗体の夕区応寸るといわれて拉 る。よつて，2-ME 処理血清と非処理血清の中和抗体を L. KL. KKL. KKK 拉よび，自然麻疹，小児科医血清 について検討した。

1. ワクチン完了後 1 力月, 初回接種後 6 力月执よび 1 年後の麻疹 NT 抗体

2-ME 処理血清と非処理血清について, NT 抗体価を 比較するに，接種後の上記期間においては L. KL. KKL. KKK 方式の如何を問わず，殆んど同程度の平均抗体価 
を示した。

この成績を各個々の血清について，Booster effect の 歹られた群，才なわち，6力月又は 1 年月に不顕性感染 により抗体上昇したと思われる群としからざる群にわ和 て観察するに，2-ME 処理，非処理血清間飞 NT 抗体 価には差異がみられなかった。

2. 自然感染麻疹血清中の $2 \mathrm{ME}$ 感受性抗体の 逐日 推移

自然麻愫 9 例の発疹者当日より，15日迄の血清につい て, NT 抗体を 2-ME 処理血清と非処理血清について

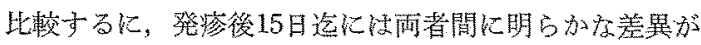
みられ，発疹4 日目以後注非処理血清の NT抗体洒证高 く, 2-ME 処理血清の抗体価は低くなっが，30日後玨 何れも略等し々高随を示した。

3. 小児科医の 2-ME 感受性抗体

麻疹患児と接触の樑い小児科医の血清にていては他の 成人血清より抗体価が高いが，2-ME 处理血清と非処理 血清についてNT 抗体を比較するに殆んど同值であっ た.

\section{DPTM 混合ワクチンの接種実験}

新しいワクチンの開発につれで，小昌の予防接種の回 数峐珈するのみであり，母子対する負担，苦痛も大 きく，接種率の低下む夏慮されるとこるで西る。

その解決策として混合ワクチンの試多がなされ，すで にDP。あるいは DPT 混合ワタチンは実用化されてい る。麻疹ワタチンをこれらロクチンに組达み，乙かも免 㾤效果が互に干渉さ机ずに相乗さるれれ゙結構であるら。

かかるに見地から DPTM 混合ワクチンの接種寒駼を 行なっているので成績の一端を述べる。

方法. 対象

DPTM：生後 3 力月 10月, 健康乳児 28 例

$\mathrm{M}$ ：麻疹既往のない 9 力月～ 5 歳, 健康小児19例

D：デフテリナ菌トキソイド６0Lf。

$\mathrm{P}$ ：百日崚菌ワクチン 15bil,

$\mathrm{T}$ ：破傷風菌トキンイドー10Lf.

$\mathrm{M}$ ：不活化麻侩ワクチン $\quad 4^{3}(\mathrm{AEL}) / \mathrm{ml}$.

注射以皮下，注射量下記 $\mathrm{ml}$.

何九も 4 週間隔で 3 回接種後, 4 週後に採血し，接種 前と比較した。

$\operatorname{DPTM}\left\{\begin{array}{llll}\text { A } & \text { I } & \text { II } & \text { III } \\ \text { B } & 0.5 & 0.6 & 1.0 \\ \text { C } & 0.5 & 0.6 & 1.0\end{array}\right.$
$M\left\{\begin{array}{llll}\mathrm{D} & 0.5 & 1.0 & 1.0 \\ \mathrm{E} & 0.5 & 0.6 & 1.0\end{array}\right.$

1。主な臨床反応
隐床反応調查方式汸アンケート方式による。

調查事項: 発熱日, 発熱の高さ, 持続日数, 発疹, 注射 部位の発赤, 硬結, 疼痛招よびそれらの持続日数発熱俚 DPTM 群で第 1 回目に $3 / 2$ （10.7\%) 第 2 回目飞 $2 / 28$ $(7.1 \%)$, 第3 回目に $7 / 27(25.9 \%)$, 計 $12 / 83(14.5 \%)$ 亿 矢, 発熱日社, 注射当日 8 例, 翌日 3 例, 翌々日 1 例で 要り，持続日数好 1.7 日，1.5日，1.4日，平均 1.5 日で 高さ注何孔も $39.0^{\circ} \mathrm{C}$ 以下で平均 $37.9^{\circ} \mathrm{C}$ であった。 こ の発熱娃混合ワクチンに関する研究委員会報告の DP ワ クチンの成績と比較してPワクチンによる発熱と孝光ら 机た。

注射部位の局所反応梳，発赤を20/83（24.1\%）飞約 3

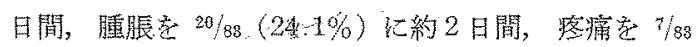
(8.4\%) に約 1.5 日間みた。一方 M 群で第1 回目に $8 / 19(31.6 \%)$ ，第 2 回目 $1 / 10(6.3 \%)$ ，第 3 回目に $1 / 14$

(7.1\%) 計 $8 / 49(16.3 \%)$ 飞, 注射後 6 8 日の間に平

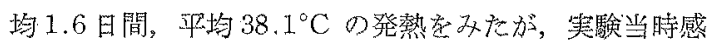
冒の流行があっていたので，ワクチンの影響と法断言で きない, 又注射部位心発赤 3 例, 腫脤 2 例, 疼痛 2 例を 两た。

2. 麻骖抗体産生状況

DPTM 群 21 例のペア血清について比較するに，接理 前 NT 抗体平均価0より 5.62 亿上昇し，陽転率 100\% を示し，M群でも平均抗体価 5.85 となり，陽転率 $100 \%$ を示した。

HI 抗体では，DPTM 群平均抗体価 5.94 となり，100 \%の陽転率で㐫り，M群も5.92，100\%の陽性率安示し 両群間の効果に差異以みられない。

3. D. P. T 抗体産生状沉

ペア血清 10 例に技いてDの接種前抗瑇素価は $1 / 10$ 単 位 1 例, 他位 $1 / 30$ 単位以下であつたが, 接種後は何れも $1 / 30$ 単位以上亡なった。

$\mathrm{P}$ の接種前凝集素优 は 1 例 20 倍, 他は 0 であつたも の゙，160 倍 3 例，320倍 4 例，640倍 2 例，1280 倍工例 となった。 又破傷風抗毒素価は接種前何孔も 0.01 以下 上り, 接種後 0.36 単位 2 例, 1.2 単位 3 例, 2.4 単位 5 例となった。

以上 DPTM 混合ワクチンの接種は互に干渉すること

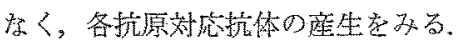

これらをDP 混合ワクチンやDPT 混合ワクチンの接 種報告と比較するに，百日暗菌量の低い DPTM 混合り クチンに扔いて，Pの凝集価の上昇はやや劣るが，D.T の抗毒素価の上昇法をしろ優れた成績を示し，少く共混 合ワタチンとすることにより不刹な影響社みられなか 吃.

今捘更に抗体の長期效果などについても造及する予定 
である。

以上かんたんに現在の麻疹ワクチンおよび麻疹混合ワ クチンの免疫学的研究の一端孛述べた。

\section{2. 日本脳炎}

\section{a. 長崎県下住民の日本脸炎ウイルス免疫抗体 の保有状況について}

\section{层崎県衛生研究所}

䯩 橋 克 巳

我国に打ける日本脳炎（JE）の流行には，その患者発 生数の年次的変動吕可成り大きく見られ，又，同一年で も患者発生密度に地域的差異吕著しい。この椂な, JE 流行の時間的, 空間的変動注, 何によつて規定されるの であろらか. JE 流行を規定する基本的要素としては, 一定地域に抒汀るJE ウイルス（V）散布度と，その地 域住民の JEV 感受性個体数の三つの因子妿考えられ， 両者の量的相関が，毎年見られる JE 流行の少イズに密 接に関係していると思われる。前者は，JEV 保有媒介 蚊個体の絶対数で表現され，その年による変動は大きく 疫学的には JE 流行の一次的要素として重視されてい る. 後者は，地区住民の JEV 中和抗体保有状況で表現 され，それ注大部分過去に打けるその地域のJEV 不顕 性感染による自然免疫と，JEワクチン接種による人 工免疫の和の累積で構成されている。したがつて低率 と見られる不影性感染と，著増を見ないワクチン接種 の普及度より考えて，これ注比較的変動の少ない，固定 化したものと考えられて来た，然し，最近，中和抗体測 定法が，組織培養技術の進歩によつて，従前に比べ，遙 かに精密化し, 且, 検体の大量妈理が容易となつたため 従来察態不明のまま莫然と，疫学的意義が二次的である とされた地区住民の中和抗体保有率の JE 流行に占める 比重について, 再検討を行なら必要があると思われる。 加らるに，近来，JE 流行に対する社会的関心の昂揚に 伴い，流行防止の具体的，且，実際的詨策として JE ワクチン接種の普及が強力に推進されね枋ならない現状 に抒いて中和抗体保有状況の実態究明は，その普及推進 の重点指问指標としての行政的意義も大きくなつて来て 、る、この樣な観点加ら，演者等は，九州地方に招け るこの種調查が少なく、この実態は不明な事が多いので 戦後最大の JE 流行直後の1966 年 10月の時点で, 長崎 県下 3 地区の住民集団について, JEV 免疫抗体の保有 状況を，地区別，年龄別に調査し，併せてその地区の JE 流行サイズとの関連を検討したので以下その概要を 述ベる。

調查対象は，この年，県下で最も激しい流行に見舞わ
たれ俈世保市 (届出患者数，41名，人口 10 万刘患者発 生率 16.1) と，壱汥郡（届出患者数 18 名, 人口 10 万 效患者発生率 38.3) の芦辺町し, 対照として比較的例年 小流行に留っている南高来郡(届出患者数 4 名, 人口 10 万対患者発生率 2.6) の愛野町の 3 地区住民で，各々， $0 \sim 5$ 歳, $6 \sim 15$ 歳, 16 30歳, 31 40歳, $41 \sim 59$ 歳, 60 歳以上の 6 年蹂区分により各年齢層每にほぼ平均して 佳世保市 200 名, 芦辺町 100 名, 愛野町 224 名, 合計 524 名で何れも各市町に 5 年以上在住の者である。免疫 抗体調查として先づ赤血球凝集抑制抗体 (HI) 怄, JaGA r\#01 株のアセトン・エーテル抽出抗原（武田薬品製） を用い，血清処理はアセトン 2 回抽出処理を行い，1日 ヒヨコ血球により，予研法に準じて行なつた。中和抗体 (NT) は，JaGAr\#01株（予研分与，マウス脳 6 代通 過）在用い, ニワトリ胎児初代細胞上のプラック減数法 (予研法)により測定した。

先づ HI 価と NT 価の相関性であるが, 兩者恃, 各 地区共よく一致してほ卧線的相関分布が見られた HI 価 10 倍以下の者の中で, NT 伍马10 倍以下のものは, 愛野町 $84.3 \%$, 佐世保市 $88.0 \%$, 壳辺町 $74.7 \%$ で芦辺 町は最も少く, 可成り特異でめつた。

各地区の年齢区分別 NT 保有状況は，愛野町では年齢 の上昇と共に階段的に急速な上暴が見られ，0〜 5 歳の $40.5 \%$ が，16〜30 歳で $81.2 \%$ となり，更に $41 \sim 59$ 歳し は $67.4 \%, 60$ 歳以上 $100 \%$ で，平均 $73.2 \%$ の保有率を 示すのに対し，佐世保市では，0〜 5 歳で $34.2 \% ， 16$ 30 歳で $37.5 \%, 41 \sim 59$ 歳で $54.7 \% ， 60$ 歳以上 $50.0 \%$, 平均で $44.00 \%$ ，芦辺町では $0 \sim 5$ 歳で $26.8 \%, 16 \sim$ 30 藏，55.6\%，41 59 歳，41.0\%，60 歳以上でも 60.0 $\%$ ，平均 $40.0 \%$ と云う低率であり，年龄的な保有率の上 昇は極めて緩慢，ないし横ばい的な様相が伺われた。又 3 地区住民の NT洒と年龄区分との関係でも，愛野町で は年龄区分の上昇と共にそのNT洒の分布字高い方へ移 行するが，他の地区では，この様な傾问梳顥著でなく， 両者閒には，やはり NT 価分布の量的質的差異を示唆す るものがあった．次に 3 地区で，HI 保有率と NT 保有 率の差を見ると, 愛野町では, 再者の差は僅かに平均で, $4.5 \%$ に留るのに対し，佐世保市は $7.0 \%$ ，芦辺町注 21 $\%$ に達している. 以上の様に調査対象 3 地区の住民 JEV 免疫抗体保有率には顕著な相違が見られたが，こ れらの現象を単に都市型と農村型，あるいは本土型と離 島型の様な類型的な分類で決める事恪困難である。各地 区住民が JEV 免疫抗体を獲得する契機は，前述の様に 殆んど不顕性感染と，ワクチン接種の為であり，不顕性 感染率は，JEV 撒布密度によつて 決定されるが，それ は地区差唯あり，又年次差があり，県下均一でない事は 
当然推定される。然し興味深い事には，過去 3 力年間常 亿人口 10 万対 10 以上の $\mathrm{JE}$ “患者発生率を示して来た流 行地としての壱岐郡芦辺町の住民 NT 保有率が 3 地区中 最低であつた事実㤝，不顕性感染率乞のものが，諸報告 にも見られる様に，意外に小さいもので岁る事を裏書き すると思われる、したがつて他の急性伝染病流行後の様 に，流行によつてその地区住民の抗体保有率が激増し， 次の流行は必然的に小流行であるらと予測する原則をそ のまま，单純にJE の流行予測として適用にるには問題 がある。

以上の様に，調查対象 3 地区に関する限り各地区住民 の $\mathrm{JE}$ 免疫抗体保有率の顕著な差法，直接，昨年のその 地区におけるJE流行のサイズと極めて密接な関連性の 存在する事が指摘される。愛野町では，JEV 撒布度の 指標として，コガタアカイエカよりの JEV 分離が行な われ，并の消長ピークとの関係から JEV 保有蚊個体の 絶対数が過去 3 力年間に括いて，1966年は最も多かった であるうと推定されたが，佐世保市や芦辺町においては この調查はなされて㧍らず，したがってこの面に關して は不明で㔖るが，若し JEV 撒布度が佐世保市，芦辺町

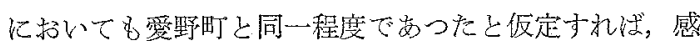
受性個体数に上述の大きな差が㚣孔ば，当然昨年の様な 地区別患者数の差となって現れる事が理論的に注肯定さ れる，又，近年，我国の JE 流行において，罹患年齢層

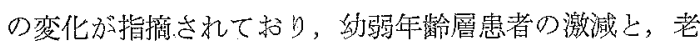
人層患者の激増が問題しなつている。この樣な現象は， 幼弱年齢層のワクチン接種普及によって前者の説明は可 能であるが，後者の理論的説明は图難である。常識的に 考穴られている愛野町の様な年齢別抗体保有状沉加云 えば，寧るこの現象任奇異な感すら与光る。然し，佐世 保市や芦辺町住民に見ら机年年龄別抗体保有状況は，或 る程度この奇哄な現象の説明飞肯定的な示唆を与えるむ のがあると考㿝られる。

從来，JE 流行の二次的要素として，実熊不明のまま 推移して来を感のある感受性個体調查は，流行の解析と その対策としてのワクチン接種普及推進の前提しして, 今後再に広範な実施と換対が必要とされる所以である。

\section{b。 日本脳炎の血清痉学一2-メルカプトエタ ノール感受性の面から一}

福岡県衛生研究所 大塚悟

Svehag 拉よびMandel1リポリオウイルス接種にとも ならウサギの抗体産生の研究以来接種のウイルス感染症 に㧍いて，動物㧍よびヒ卜の保有寸る血清抗体の接種を 検討すること代よって，感染後の時間を推定することが
行なわれている。

われわれは動物（主としてブタ）および日本脸炎患者 の日本脳炎ウイルス (JEV と略) 感染比ともなう抗体産 生を2-メルカプトエタノール (2ME と略). 感受性の面 加追求し， $2 \mathrm{ME}$ 処理法の血清疫学一の応用性につい て検討した，以下その成績につけててのべる。

1. 材料ならびに方法

i）使用動物血清：ブタ血清ほ 経歴の明らかな飼育ブ 夕と福岡, 久留米雨之畜場でと殺された生後 $6 \sim 8$ 力月 のブタから採取し，イヌ，ウシ，ウマなどの血清はいず れも経歴の明らかなものから採取した。

ii）日本脳炎患者血清：1963 1966年福岡県下で発生 した日本脳炎患者 320 名（1963 年8名，1964 年75名， 1965 年 79 名, 1966 年 158 名）より1.ないし数回採取し た血清 616 例で岁る。な拉これらの患者は死亡例の一部 を除き全例血清学的化確認されたものである.

iii）抗体価の測定法：抗体価の測定は寸べて血球凝集 抑制（HI）試験により行ない，その方法汢予研法2り準 した．抗原は感染哺乳マウス脳のアセトン・エーテル処 理のもの学用い，動物の場合は自然感染例には JaGAr抹01，ワクチン接種例には中山薬検株，感染実験例には 使用ウイルス株を，日本脳炎患者の場合は中山予研株を それぞれ使用した。血球支が鳥血球を使用し，血清は 10 倍より 2 倍階段稀勫を行なつた。

iv）血清の $2 \mathrm{ME}$ 処理と判定：血清索 0.01Mリン酸緩 衝食塩水（pH 7.2）で2 倍に稀釈し，等量の $0.2 \mathrm{M}, 2$ $\mathrm{ME}$ 溶液を加光, $37^{\circ} \mathrm{C} 1 \sim 2$ 時間後約 20 倍量の泠アセ トンで動物血清は 3 回, ヒト血清では 2 回抽出を行ない 乾燥沈渣に木ウ酸緩衝食塩水 ( $\mathrm{pH}$ 9.0) を加光, 1 夜水 室後 $56^{\circ} \mathrm{C} 30$ 分非働化，が鳥血球吸収後の上清を用い た。 $2 \mathrm{ME}$ 溶液の代りにリン酸緩衝食塩水を用い，同様 な操作を行なつた血清を対照とした、判定は一般に $2 \mathrm{ME}$ 処理の抗体価が非处理のものより4倍以下の場合その血 清を $2 \mathrm{ME}$ 感染性とし，同值また注 2 倍低值の場合洨 2 ME 耐性と判定した.

2. 成績ならびに考察

I]各種動物に抒ける $\mathrm{HI}$ 抗体の $2 \mathrm{ME}$ 感受性の検討

a）飼育ブタを用いての実験成績

自然感染例：抗体をもたないブタが自然感染をうけた 場合出現する抗体は $2 \mathrm{ME}$ 感受性で, $2 \sim 4$ 週後に $2 \mathrm{ME}$ 耐性一移行することが 1964 1966 年の3 年間にわたる

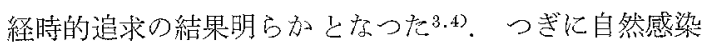
によって抗体をもつにいたつたブタで注 2 回目の越夏に 上り抗体価の上昇が認好られて子抗体の $2 \mathrm{ME}$ 感受性に 変化はなく $2 \mathrm{ME}$ 耐性であつたが 3 回目の越夏によって 抗体洒の上昇定し乞の際の抗体が $2 \mathrm{ME}$ 感受性を示す 
むのが認为られた，この例は両感染によるものとも考光 られるが，2ME-処理血清の抗体洒と非処理のものとの 抗体価のひらきが倍にすぎないことから再感染と断定す ることは困難であるう。しかしこの所見はブタが自然感 染によつて獲得した免疫の持続が 3 年程度で失わ北る場 合もありらることを示唆するものかも知れない，さら 儿血清を7S，19S 亿分画して検討すべき問題である $5^{4)}$.

移行抗体保有例：移行抗体は $2 \mathrm{ME}$ 而性で，移行抗体 保有例が自然感染の機会をもつても，抗体価に変動はな く推移する。 また $2 \mathrm{ME}$ 感受性の変化も認められない。 すなわち，移行抗体保有例では自然感染をうけて子抗体 産生の点で二次反応を㧍こさないと考光られる32.

ワクチン接種例：自然感染の場合と同様な抗体産生を 示す。すなわち，抗体をむたないブタに高力価不活化口 クチンを接種した場合出現する抗体は $2 \mathrm{ME}$ 感受性で, その後の追加接種により $2 \mathrm{ME}$ 臫性へ移行する。 またり クチン接種により抗体をもつにいたつたブタが自然感染 をうけた場合には二次反応として $2 \mathrm{ME}$ 耐性抗体の出現 をみることが経時的追求の結果明らかとなつた ${ }^{3.4}$.

感染実験例：自然感染の場合と同㥞な抗体産生がみら れる，すなわち，ブタ血液より分離した初代株の FS134 株 $\left(10^{7.3} \mathrm{LD}_{50} / 0.03 \mathrm{ml}\right)$ の $10^{-1}, 10^{-2}, 10^{-4}, 10^{-5}$ 稀勫 ウイルス液を $1 \mathrm{ml}$ あて抗体のないブター皮下接種し経 時的に追求した結果, 出現する抗体は $2 \mathrm{ME}$ 感受性で, $10^{-1} \sim 10^{-2}$ 接種群では約週後, $10^{-4} \sim 10^{-5}$ 接種群では $3 \sim 4$ 週後に $2 \mathrm{ME}$ 耐性一移行した. この所見はブタの 場合接種ウイルスの量的差異によって $2 \mathrm{ME}$ 感受性抗体 の持続期間が異なることを示すものと思われる。したが つて自然感染例にみられる抗体産生の個体差は感染ウイ ルス量によるものと考えられるが，娃娠時の感染などの 個体条件儿よる感受性の差も考光られ，さらに検討要要 する問題であるう。つぎに抗体をもつブタに JEV を接 種した場合に法抗体の $2 \mathrm{ME}$ 感受性㹥変らず $2 \mathrm{ME}$ 而性 であつた，香た接種径路が異なつても出現する抗体の 2 $\mathrm{ME}$ 感受性に注変化がみられなかった。

b） $2 \mathrm{ME}$ 処理法によるブタの JEV 感染の実態調査 飼育ブタを用いての実験の結果, $2 \mathrm{ME}$ 感受性抗体は 感染初期とワクチン接種の場合にだけ出現することがた しかめられた。このことはブタ血清の $2 \mathrm{ME}$ 感受性を検 討することにより JEV 感染の時期つまり JEV の動態 を推察することが可能であることを意味する。われわれ は 1965 1966 年の 2 年間 JEV 流行の初期 ( $6 \sim 8$ 月) に採取したと場ブタ血清について $2 \mathrm{ME}$ 感受性抗体の出 現状況とウイルス血症との関連性を追求し, ブタのJEV 感染つまり JEV の拡がりには地域差が認められること
ブタに打汀る感染江 2 3 週以内に一斉に扔こるすので 㐫り，今野らうの成績とほぼ一致することを認め，ウイ ルス血症の時期と $2 \mathrm{ME}$ 感受性抗体出現状沉そが密接な 関係があることをも明らかにした。

つぎに JEV 流行閑期（1964年10月～1966年 5 月）に $\mathrm{HI}$ 抗体老保有するブタ 173 例について，抗体の $2 \mathrm{ME}$ 感受性検討した。 その結果 1965 年 3 月, 4 月および 10 月に各 1 例岁ての 3 例飞 $2 \mathrm{ME}$ 感受性抗体䘮保有ずる ブタを証明した、このことは JEVの越冬の問題が未解決 である現在興味ある事実を提供したものと思われる4)。

c）ブタ以外の動物に扝应抗体の $2 \mathrm{ME}$ 感受性の検 討

イヌ：抗体のない例为感染をうけた場合出現する抗体 は $2 \mathrm{ME}$ 感受性で，㐫る期間を経て $2 \mathrm{ME}$ 耐性抗体一移 行することが，自然感染例，感染実験例に打计る経時的 追求の結果明らかとなった。しかし感染をらけても抗体 産生が極好て悪く，接種後 22 日目に抗体の出現をみた あと死亡した例もあうたことは注目すべきことと思われ る.

ウシ, ウマ, ヤギ：ウシ，ウマも感染初期化は $2 \mathrm{ME}$ 感受性抗体の出現をみるが, 経時的追求例が少なく, 2 ME 感受性抗体の持続期間は明らかでない.ヤギでも2 $\mathrm{ME}$ 感受性抗体の出現をみるがその持続期閒はブタより “短い上うであるが例数が少なく検討の必要があろう。

II] 日本脳炎患者血清の $2 \mathrm{ME}$ 感受性検討のブタにみ られるような抗体率生がが七トの場合にも成立するか否 かを1963 1964 年福岡県下で発生した日本脳炎患者 320 名から採取した血清 616 例について検討した ${ }^{6)}$. その 結果第 21 病日までに証明した抗体は $2 \mathrm{ME}$ 感受性を示 すものが多く（約70 90\%）その後は $2 \mathrm{ME}$ 耐性を示す ものが多くなり第 42 病日以降では $2 \mathrm{ME}$ 耐性を示寸も のが優勢々なつている。な扔治療例でほぼ逐週的に追求 寸ることのできた 38 例について，2ME 耐性抗体一移 行した病日数をみると，8〜14病日に約 $29 \%, 21$ 病日 までに約 $53 \% ， 28$ 病日までに約 83\%，35病日までに約 $88 \%$ ，42病日以降には $100 \% 2 \mathrm{ME}$ 酎性へ移行した。 すなわち以上の例加ら観察すると，日本脳炎患者に打沙 る $2 \mathrm{ME}$ 感受性抗体の持続期間性個体によつて差法学る が，一般的に注 42 病日ごろまでに $2 \mathrm{ME}$ 耐性抗体一移 行するよう思われる。しかし発症直後㐫るいは 7 病日 以内記証明した抗体がすでに $2 \mathrm{ME}$ 耐性を示したものが 264 例中 34 例 (12.8\%) 亿認好られ，時間の経過ととも に专の抗体価の上昇を示したものも 34 例中 16 例（47.0 \%) 㐫つた。この所見は注目す心゙きもので，7病日以内 に証明した抗体が $2 \mathrm{ME}$ 耐性であつた理由としてつぎの 場合が考光られる。すなわち，抗体をすつ例が感染発症 
し二次反応として抗体の上昇を示した場合と感染より発 症までの時間的経過が長かつた場合などである。前者は ワクチン接種により抗体の産生をみたが，感染防禦には 不充分で自然感染により発症し二次反店として $2 \mathrm{ME}$ 耐 性抗体の出現をみたとも考えられるし，ワクチン非接種 例では，再感染により二次反応を示し，2 ME 而性抗体 の出現をみたとも解採できる。後者については，ヒトの 場合感染の時期が明らかでなく発症の月日も明確でない ものも多いことからこのような場合が存在する可能性は 充分考学られる，死亡例では検討することのできた 60 例中 55 例が $2 \mathrm{ME}$ 感受性で，2 $\mathrm{ME}$ 耐性を示した 5 例 はすべて 7 病日以内のものでかつ 61 歳以上の高年齢者 に認められ抗体価の高い例が多かったこと注目寸べき である。つぎに年齢別に $2 \mathrm{ME}$ 而性抗体が 7 病日以内に 証明された頻度をみると，30歳以下の年齢層に多くつい で 50 歳以上の高年龄層で 40 歳台の年齢層に泟明され なかった。

以上のべたように福岡県下で発生した日本脳炎患者の 感染初期の血清抗体は $2 \mathrm{ME}$ 感受性を示寸ものが多いこ とは今野らら)の報告と一致している。しかし今野らの報 告では 7 病日以内ゆ抗体はすべて $2 \mathrm{ME}$ 感受性を示した ものと異なり，7 病日以内の抗体がすでに $2 \mathrm{ME}$ 耐性を 示寸ものがが方りの数に認められた。このこと注抗体を もつ例で品感染発症寸る場合があることを示唆し，さら に再感染の存在も否定できないよらに考えられる。した がつて今野らが報告したように，発症初期の血清抗体に ついてその $2 \mathrm{ME}$ 感受性を検討寸るだけで，日本脳炎の 血清学的診断が可能の場合も多いであるうが，流行の地 域によつては $2 \mathrm{ME}$ 処理だけでは血清学的診断が可能で ない場合も文り，石井ら7もの心゙たように $2 \mathrm{ME}$ 処理法 を日本脳炎卑者の血清学的診断へ応用することについて 注さらに検討の必要があるう。

\section{3.むむび}

以上 JEV 感染にともなう抗体産生を動物および日本 脳炎患者にういて $2 \mathrm{ME}$ 感受性の面から検討を加えた結 果, $2 \mathrm{ME}$ 处理法の血清疫学への有用性が認站られるが さらに検討すべき余地も残されており，今後の追求が望 まれる。

\section{文献}

1) Svehag, S-E and Mandel, B.(1964): J. Exp. Med., 119: 1-19:21-39. -2) 国立子防衛生研究 所学友会編”: ウイルス奏験学各㖮, 1967版, 丸善. 東 京，一-3）大塚悟，真子慧治，秝良一，国広英文。本 村一郎 (1966)：日本細菌学雜誌，21：724-730. 4）大塚语，真子憲治，森良一，国広英文，本村一郎 (1967)：日本細菌学雑誌，22:250-255。一- -5) 今野

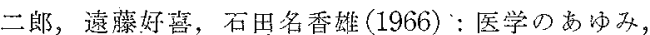

58：703-708. 一6) 大塚悟，真子㥶治，㷊 良一。 (1967)：日本細菌学雑誌，22 巻 5 号掲載予定。一7) 石井慶蔵，松永泰子 (1966)： ウイルス，16：192193 敊よび私信.

\section{3. インフルエンザ}

a.インフルエンザにおける免疫

九州大学医学部第一内科

加 地 正 郎

\section{1. 免疫の成立}

実験的インフルエンザでは，ウイルスは呼吸器で増殖 し，血流あるいはリンパ流による全身撒布，局所撒布に よつて,リンパ腺, 脾;骨䯣に達し，抗体産生が開始され， る。体液性抗体㹥，他のウイオン感染と同様，最初 19S ついで7 Sが産生される。

人のインフルエンザでは，ウイルス血症は就こらない と考光られていたが，最近，脾，肝，䇾，リンパ腺など からウイルスが分離され，また急性期患者の血液からの ウイルス分離も報告されて㐜り，免疫の成立にもこのよ らな機序の考慮が必要となってきている。

2. 自然感染免疫

年齢的な抗体分布をみると，母親からの受衔免疫がな くなると生後 1 年前後を最低にして，その後は自然感染 をくりかえすことによって，抗体は年齢とともに上昇し 昰年年齢層（地域气の他の条件により一定しない）にな ると一定の水準佳達劣上考光られる。

しかし，インフルエンザウイルスでは，たえず抗原構 造の変遷が办られるので, 自然感染免疫の解釈悔復雑と なる。またこれに関連して，抗原原罪説の考光方は興味. 深い。

\section{3. 感染防輩}

インフルエンザの感染を防禦するのに最も重要な役割

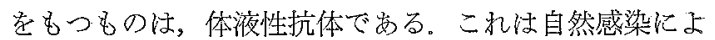
るもの，ワクチン接種によるもの，いずれも同じで，抗 体価の高いものは罪患率が低く，抗体価の低いものほど よく罹患する。この感染防禦に必要な抗体価のレベル 以，赤血球凝集抑制価で 64 128 倍と考光られ，ワクチ ン接種の際の一応の目標となる。末た罹患した場合，亦 る程度の抗体があれ壮症状法軽くてすむ。

自然感染後の免疫の持続は，それほど長いもので法な く，再感染の例もみられるが，くりかえしてインフルエ ンザに罹患する事実はむしろ流行の度毎に観察される病 原ウイルス株の抗原構造の变異から説明される.

体液性抗体の他に，組織免疫の可能性も考えられる， がままだ実証されていない，感染後の一時的な非特異的 抵抗法実験的に証明されている。 
ワクチン接種

ワクチンによる免疫は, 水性ワクチンでは接種後 2 〜 4 週で最高に達し，感染防禦に有効な抗体レベルは少く こも $3 \sim 7$ 力月間恃維持されるが，以後はかなり急速に 低下寸る。しかし，再接種に上る抗体上昇注急速加高 度である。

アジュバントワクチンを用いると，抗体の上昇度拉よ びその持続は水性ワクチンにくらべて極めて高度であ り，接種 1 力月後に性充分な抗体産生がみられ，更に3 カ月後まで抗体の上昇が続く。その後の下降もゆるやか で，1年後でも抗体価のレベル滈い。

また水性ワクチンの際にはタられない broadening of antibody response が証明されるのが注意をひく。

\section{b. インフルエンザの血清疫学的考察}

化学及び血清療法研究所

石田弘

免疫は先ず感染に依つて成立し，免疫のない感染の終 局は只“死”亦るの文。㝘葉を替えて云えば，免疫とは 感染の成立を阻ばも5とする生体側の力であり，感染と は，免疫と云う障害突破して前進しようとする病原体 の力である. 即ち，感染と免疫は不即不離の関係にあり 生体が感染を受けた時，再度の感染を阻止しようとする メカニズムがその生体内に成立卞る，そして血清中に感 染抗原に対灾子る抗体を産生する. その現象索免疫と云 い，その抗体量は免疫度表わす. 而して感染経過の後 に於いても或る期閒存続する，徒つて抗体の有無注感染 の有無と相通ずる、此処に血清没学の瑒がある. 即ら血 清疫学と梳効照集団に於けるある時点での抗体消長の実 態を把握し, 感染症の流行の生態を探るらとする学問で ある、インフルエンザに於いても一般感染症と何等異る ところはない，即らインフルエンザウイルス抗原に対応 寸る抗体を謂心゙る事に依つて感染の有無確認が可能であ 万.

インフルエンザ抗体の測定方法に柱禣体結合反応 (C. FT) と血球凝集抑制反忘 (HIT) 及び中和試験 (NT) の3つの方法があるが，通常煩雑な CFTよりす比較的 操作の簡単でしかも持続期間の永い HIT が一般に多く 用いられて㧍り，今回洼特にHIT は限定して論旨を進 める.

インフルエンザウイルスは $\mathrm{V}$ ¿ $\mathrm{S}$ のつの抗原から成 り立ち，V抗原は又ウイルス抗原とも呼ばれ，粒子の表 面を構成する表在性のもので，血球膜を形成する 1 種の ムコ䖤白と結合する性質を持つていて血球を凝集する。 このV抗原に対応子るV抗体はV抗原をブロックして，
その活動を停止させる，従つて「ウイルス抗原の持つ血 球凝集能を封鎖する性能を持つ」と云う事は，その抗原 に效応する抗体の存在を示子事になる、つまり血清中の 抗体の有無並びにその量を知る為めには「血清の血球凝 集抑制能定訜べればいい」と云う事である。

さて熊本地区に於いて注今年も又 1 月中旬垻より，イ ンフルエンザの地区的な小流行が発生し, B型ウイルス に依る流行である事が確認されているが，その閒に極め て小数例乍ら $\mathrm{A}_{2}$ 抗体佂が買常に高いものが散芫される ので, $\mathrm{B}$ の顕性流行に隠れた $\mathrm{A}_{2}$ ウイルスに依る潜伏感 染の存在を疑い，2，3地区の集団別に抽出した血清の 抗体保有状沉の分析を行い，その成績について血清疫学 的な考察を行つて見たい.

疫学悟因, 宿主, 環境の 3 要素の上に成立する。血 清没学を論ずるにも又それらの要素を無視することは出

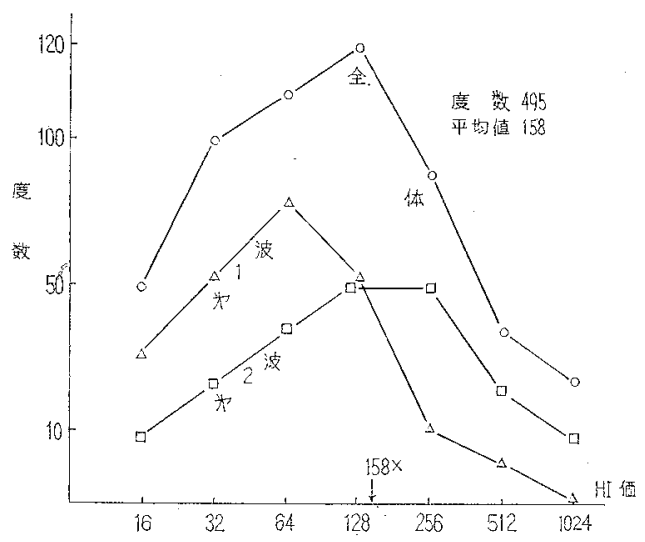

図-1 (参考) 回復期患者の抗体分布図 全国検柤成績（アジアカゼ流行史所载）

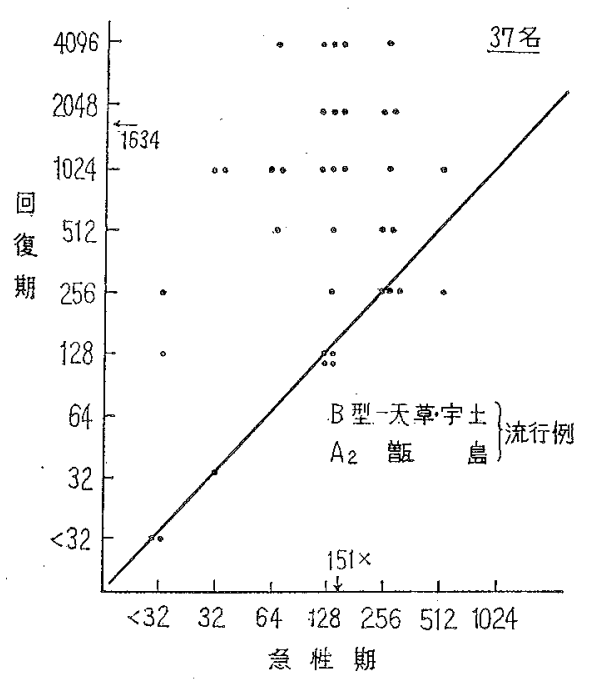

図-2 1967年春に於けるコル患者血清の HI 抗体価 抗体上昇 $(26 / 37)$ 
来ない，特にその集団の環境が占める比率注極めて大き いと思わ权代ならなだろう，更に又時点についても充 分に考慮して考察を進める心゙きであらう。

抄録に若干触れている“被感染想定值”つまり，近時 点に於沙る感染経過者々認める抗体価の算出に当つては 特に然りと思われる。

参考にアジアかぜ流行史所齓より引用した図 1 は，殆 んど全ての人々が最初の洗礼を受忛たアジアかぜ流行当 時の調查成續で, 云うならば, 初回免疫に依り獲得した 抗体像と考光るべきで，その後 10 年の歳月を加けて図 度かのブースタ一免疫を受けたであららと考光られる何 2 の示寸抗体価とは大幅な相違のある事は当然と云えよ

う。しかも図2 亿揭げた成績は抗体佂の最高值と考え られる感染経過直後に於ける回復期血清の測定値で, 平 均值が $160 \times$ 程度，となつているが，感染経過後 2 力 月或いは 3 力月後には 1 管或いは 2 管程度の低下があ万 ら事を当然考えられる問題であり, 現在一般に使用され ているワクチンが，加地博士の紹介されたアジュバント ワクチンに見られるような抗体価の上昇洁有り得ない之 すると, $512 \times$ 程度の抗体価は, 比較的新しい過去に於 ける感染と考学るべきであろう，又「環境による影響む 考慮す心゙きである」と考える根拠について，極めて極端 なケースではあるが，図 3 に示して紹介する。このデー 夕は 1964 年天草株流行の年に於恀るもので，化血研门

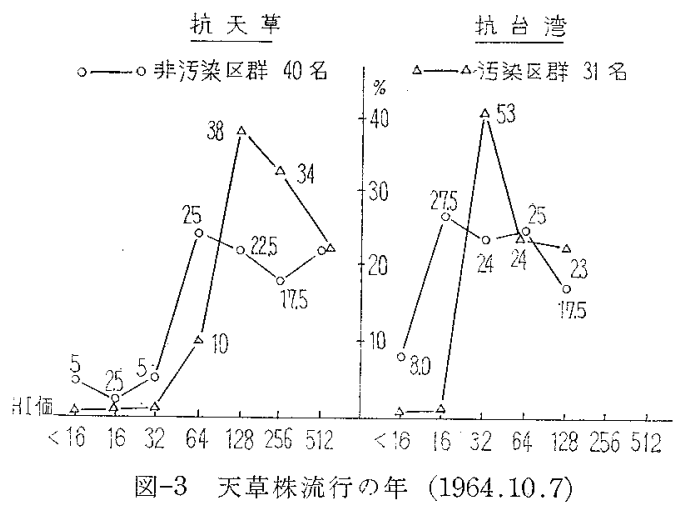

イルス課勤務職員について調查した成續である.

污染区群とは日常生ウイルスを直接取り报ら職場の勤 務者, 非污染区群とは生りイルスと㥀接関係のない場 所のもので，図に示寸通り全く吾国に流行が見られなか つた台湾株で，非污染区群で注約 $35 \%$ が殆んど抗体を 持たないのに比心，污染区群で社全員 $32 \times$ 以上の抗体 が証明されている。その傾向は左図の天草抗体に招いて む同様で，生ウイルスを取り颃ら業室に於いては不知不 識の間に生ウイルスに依る暴露感染を受けていると考え さ吼られる成績で，「環境の影響」を表明するものと云え
よ5.

以上のような基礎的な考え方に立つて，今回調査して 得た成績について解析を行つて見る。抗原は $A_{2} /$ 熊本し $\mathrm{B} /$ 札幌の 2 種類とした。最初に本年 3 月上旬 $\mathrm{A}_{2}$ によ る流行を見た鹿児島県下鼠島手打小学校に於ける調査成 績を紹介する。本調查流行の終末直後に行つたもので

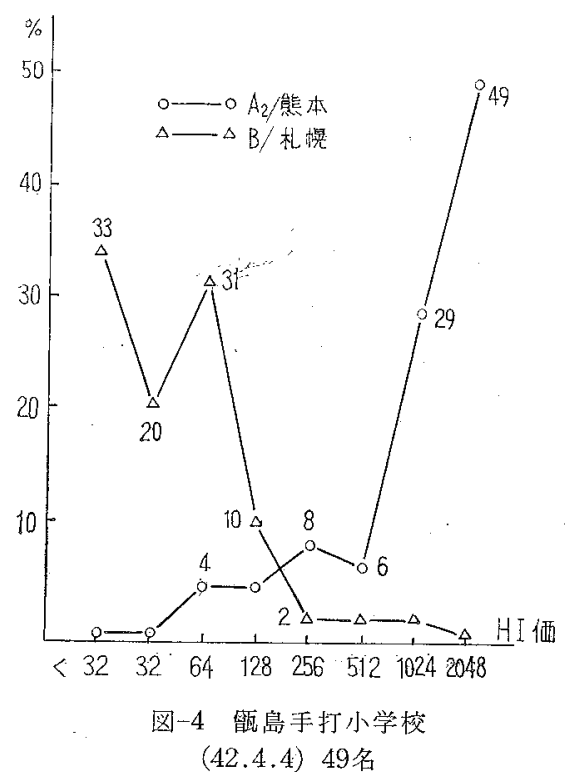

図 4 亿示す通り検査対照の $84 \%$ に $512 \times$ 以上の $\mathrm{A}_{2}$ 抗 体が証明され，可なり激しい流行であつた事が判るが， 図が示す通りその間少数例にB型に罹患したと思われる ものがあり， $\mathrm{A}_{2}$ による主流行と共にBの潜伏流行があ つた事を示すものと考えられる。但し過半数にB抗体の 低いもの，即ちBの感染対照となり得ると考えられるも のがあるのに, 何故Bに依る顕性流行が発生しないのか 理解に苦しむ処であるが，フル流行発生のメカニズムの 複雑性を物語るものと解す心゙きか. 又天草, 宇土文び鹿 児島本士にB型フルの流行が発生している同じ時期に, 手打小だけに何故 $A_{2}$ の流行が発生したか? “発生源は 何処に岗つたのか”と云ら事も不可解である。偶々, 近 接寸る自衛隊に 2 月頃かぜ様疾患の発生が女つたと聞き 4.月に現地調查を行つた。

その成績を，同じ頃調查を行つた阿蕉郡錦野小学校の ものと共に図 5 に示す.

成績が示寸通り (図 5 の左参照) 僅か数\%に $\mathrm{A}_{2}$ 感染 経過者と思われる例が見られるが，大半以上の者が $\mathrm{A}_{2}$ ， B共に抗体が低く所謂“フルの流行”が女つたとは考え られないが， $A_{2}$ にる “くすぶり流行”があつたらし い事は伺える。そして恐らくは，この潜伏流行が，“へ んすうの処女地帯” 乎打小学校で顕性化したものであろ 


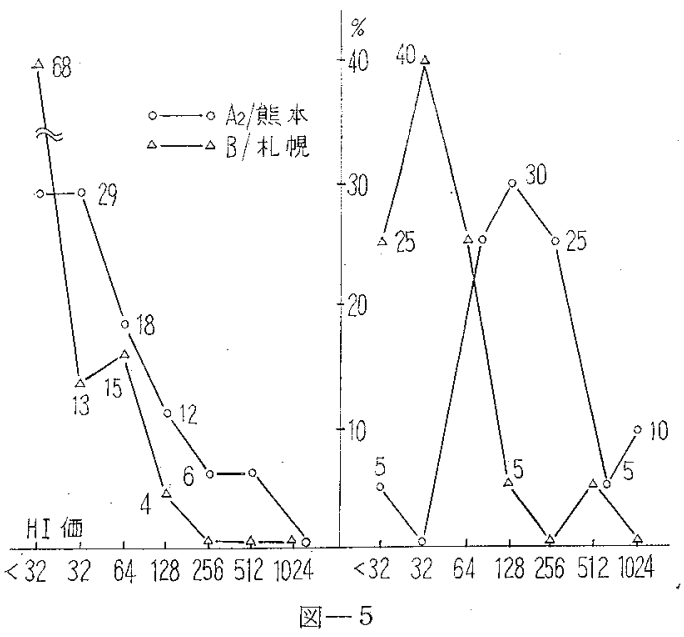

鶂島自衛隊員 (68名) 錦野小学校 (20名)

うと想像される．而乍，隊員の 70\%以上の者が $\mathrm{A}_{2}$ の抗 体洒が低く，感染待期の状態にあるものと考光られるの に何故流行が発展しないのか？ 解析は困難である。そ して隊員の殆んど 100\%の者がBフルに対して感染待期 の状態にあると云えよう。

錦野小学校では 2 月頃かぜらしい患者が若干名あつた と云われる通り、データの上でも $\mathrm{A}_{2}$ 亿依る小流行があつ た事起示している。但し 128 256×にか汀て $A_{2}$ 抗体の ピークが見られる事は，比較的新しい過去に $\mathrm{A}_{2}$ に依る 可なりの流行がめり，その流行の尾が今春㐫で潜伏流行 として存在していた事が推諭出来よ5 (図 5 の右参照).

昨 66 年は熊本県内の 1 部に $\mathrm{B}$ 型に依る小流行の 発生 が見られたが，この錦野には浸入はなかつた模様で，B 抗体の低いものが大半を占めておう，B型フルの流行発 生の可能性を示唆している.

処で，化血研臨床検査課には季節に余り関係なく，殆 んど年間を通じてポツポッとフル検査を目的とした血液 が送られて来る，そして本年 2 月頃に汹それ等の中に
$\mathrm{A}_{2}$ 抗体の異常に高いものが散見されるので，12月から 3 月にか汗ての成績を集計した，尚熊大貴田小坚科教室 に依頼して同時期の血清を提供して戴き供試した。

成績を分析すると， $64 \times \sim 256 \times$ 纪渉って(図 6 の左参 照） $\mathrm{A}_{2}$ 抗体の山見られ， $128 \times$ の処に Bのピークが見 られる処加ら， $A_{2}, B$ 共昨年夏加秋頃に加沙て若下 の流行があったと考光られる成績で，しかも $\mathrm{A}_{2}, \mathrm{~B}$ 共に 極めて新しい過去の罹患者の存在を示しており，共に不 顕性流行名肯定出来ると思う，化血研臨床検查課扱いの 分では $256 \times$ の所に $\mathrm{A}_{2}$ の山があり，512× 1024×に 涉つて若干例の抗体保有者が見られBの抗体住大部分の 者が低いが， $\mathrm{A}_{2}$ と同梯少数例に異常に高いものがあつ て，小児科材料と若干相似た傾向を示している（図6 有 参照)。

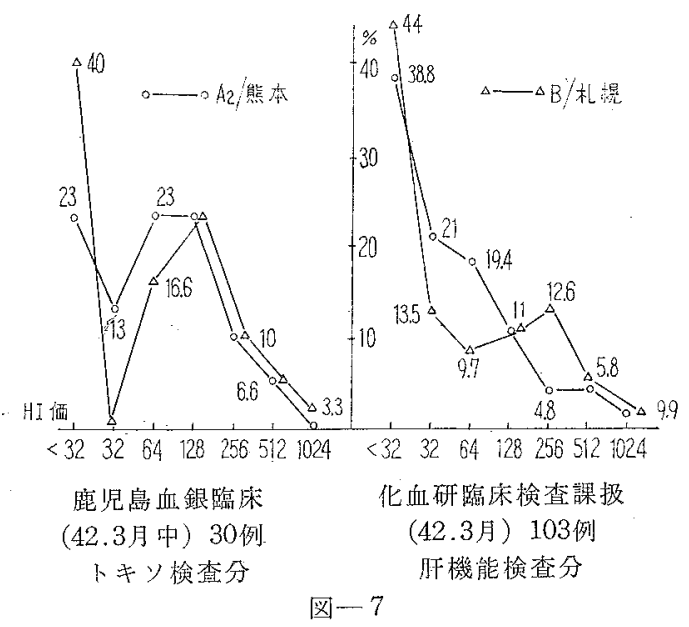

最後にかぜ疾患とは無関係と思われる鹿児島血銀トキ y検查用 30 例, 化血嘫臨床検查課扱いの 肝機能検查用 103例の成績を図 7 に，化血研ウイルス課員 93 例と同時 期の臨床㭘查課扱いのワッセルマン用57例の成績を図 8 に示した.どのグループも相似した成績で少数例の高い

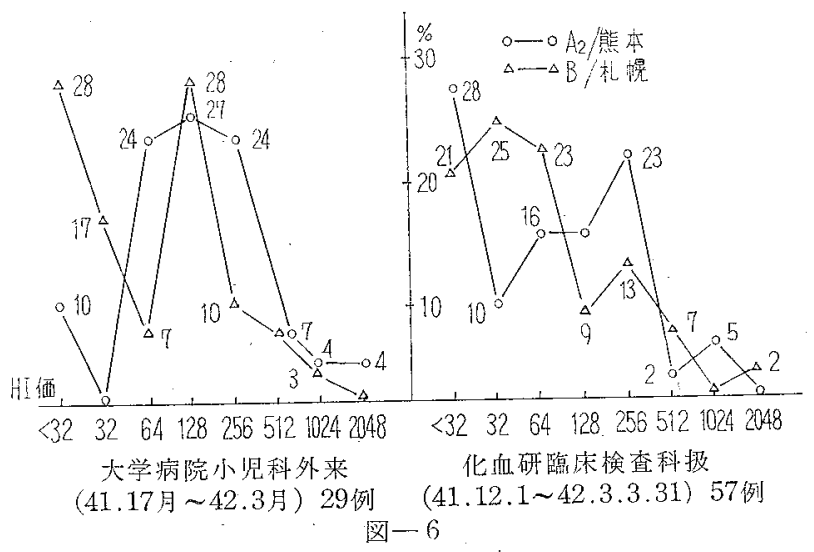




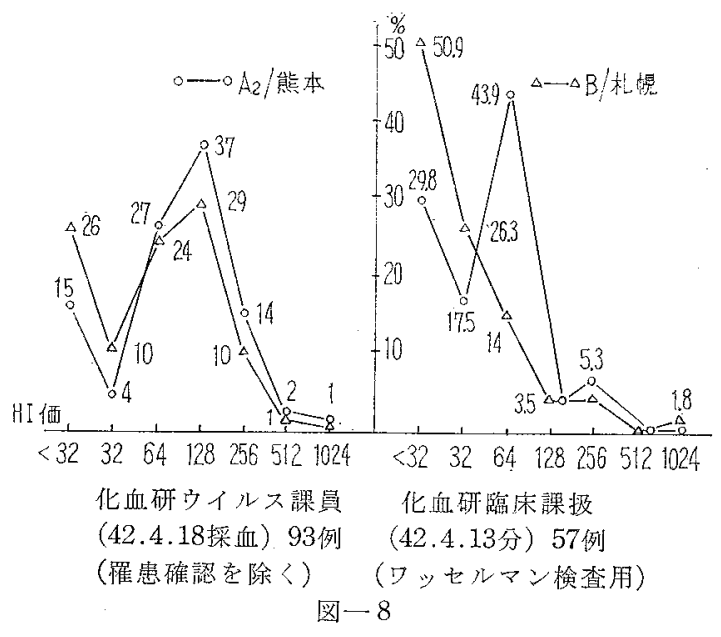

抗体価を示すものがあり， $\mathrm{A}_{2}$, , Bの両者共に潜伏流行の 存在を肯定させる成績と云えよ5。化血研ウイルス課員 の分で $128 \times$ と < $32 \times$ の部分に山が見られるが，<32× の分法 $95 \%$ が今年の新卒の職員で占めていて，余り予 防接種を受けてなかつた事老物語るものと考えられる。

以上の成績から「機至れ代風のように出現し，又忽ち にして風の如く去り，その去来，上うとして把へ難い」 と考えられているインフルェンザウイルスは, 所謂流行 閑期にも吾々の周四から完全に消えてなくなるのでなく 意外にも吾々と共にヒッソリと同居しているらしいと云 う事も考え衫隹ならなかと思う。そして機至れば（抗 体バリア一の弱体か又はウイルス自身の持つウイルレン スの復活汃，或い:抗体耐性に獲得…これ注抗原変翼 と呼ぶべきか子知れない....) 笑然「吾此処にあり」を 云う華やかな名乗りを挙げるので梳なからか?」と云 ら考え方も㻎なしとは云えないであるらと考える。

終りに, 本日引用した成績は, 熊大微生教室, 熊本県 衛生研究所及び鹿児島県衛生研究所と化血研フル研究グ ループとの共同調查に依るもので女ります. 又小児血清 は熊大貴田小児科教室から提供して戴いたものでありま 寸此処に厚く敬意学します。

\section{4. 胸腺とウイルス感染症}

\section{九州大学医学部細菌学教室}

森良一

胸腺の機能に関して 従来不明な点が多かつた。Miller, Good らによつて 1961 年, 胸腺が晡乳動物の免疫 能力の発達と重要な関係をもつことが報告されて以来， 胸腺と免疫の関連に関する研究が著しく進歩した。マウ ス，ラット，八ムスター，ウサギなどで新生時胸腺摘出 を行なうと，(1)血中抗体の産生，(2)遅延型過敏症反応，
(3)同種移植免疫等の免疫反応が低下することが知られて いる、したがつて, 新生時胸腺摘出をちけ免疫能力が低 下したいわゆる低免疫動物は，感染症の研究に於て感染 防推の本態の研究に役立つものと考觉られる。

新生時胸腺据出動物に和ける感染症については以前子 でに報告したが1223)，ここでは CF 1 (Colony-bred) 又 は SL（近親交配）マウスを用い，単純ヘルペスウイル ス (HSV)。エクトロメリアウイルス, 日本脳炎ウイル ス (JEV).リンパ球脈絡䯣膜炎 (LCM) ウイルスの感 染の経過に打忊る感染防缶免疫に及仗寸新生時胸腺摘出 の影響につ々て検討し，その結果から，これらのウイル ス感染症における感染防禦免癛の本能および感染症成立 の機作について考察を加えることにする。

[1]単純ヘルペスウイルス (HSV) ${ }^{4)}$.

無毒株 HSV である $1019 \mathrm{Cl}$ 株 (横浜市大吉野教授よ り分与をうけたもの) で免疫し，毒力株 HSV で攻撃し 感染防禦能に及ぼす新生時胸腺摘出の影響を検討した。 HF 株を用い腹腔内接種に攻撃した場合，およびヒト口 脣へルペスからの新鮮分離株である HY 株を用い，皮 内接種して攻慗した場合の死亡率打よび皮膚に打けるへ ルペスの形成を表 $1 ， 2$ に示す。これらの表に明らかな

表 1 Mortality of Immunized Mice after Intraperitoneal Injection of Strain HF of Herpes Simplex Virus.

\begin{tabular}{c|l|c}
\hline Immunization & Neonatal Operation & Mortality \\
\hline \multirow{3}{*}{ Immunized } & Thymectomy & $5 / 9$ \\
& None & $0 / 8$ \\
\hline \multirow{3}{*}{ Non-immunized } & Thymectomy & $7 / 12$ \\
& None & $7 / 15$
\end{tabular}

表 2 Mortality and Development of Herpetic Skin Lesion in Immunized Mice after Subcutaneous Injection of Strain HY of Herpes Simplex Virus.

\begin{tabular}{l|l|c|c}
\hline Immunization & Neonatal Op. & Skin Lesion & Mort, \\
\hline \multirow{3}{*}{ Immunized } & Thymectomy & $8 / 11$ & $8 / 11$ \\
& None & $1 / 8$ & $0 / 8$ \\
\hline \multirow{3}{*}{ Non-imm. } & Thymectomy & $10 / 10$ & $10 / 10$ \\
& None & $9 / 9$ & $9 / 9$
\end{tabular}

ように, HSV に対する感染防御能の成立は 新生時胸 腺摘出によつて著るしく阻害された，一方，免疫を行な つたマウスにつねて中和抗体価を測定したところ，表 3 に示すごとく，新生時胸腺摘出群，非手術群に於て殆ん ど差異を見出することができなかった，新生時胸腺摘出 
表 3 Production of Neuralizing Antibody against Herpes Simplex Virus in Immunized Mice.

\begin{tabular}{l|l}
\hline Neonatal Operation & Neutralizing Antibody Titer \\
\hline Thymectomy & $<80,80,80,80,160,160,160$ \\
Intact & $80,80,80,80,160,160$ \\
(Non-immunized mice) & $<80,<80$
\end{tabular}

Mouse serum $0.2 \mathrm{ml}$

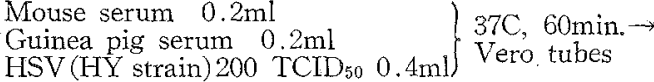

マウスで沙中抗体の産生が抑制される場合があるが， 抗原の種類, 免没の方法によつては正常マウスと殆んど 同程度の抗体産生がみられる場合がある. HSV の場合 には 1019Cl 株の生きた HSV によつて 3 回免疾を行な つたので，新生時胸腺摘出による血中抗体産生への影響 が殆んどみられなかつたものと思われる。 したがつてこ の実験結果からマウスの HSV 感染に打ける感防御の機 作は血中の中和抗体のみによるものでないことが推測で きる。免疫されてた新生時胸腺掂出マウスのそれと殆んど 同程度である例住 Coxsackie B 5 ウイルスによる免疫の 場合にも観察された。

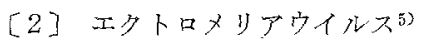

牛痘ウイルスで免疫し，エタトロメリアウイルスで攻 撃した場合の結果を表 4,5 に示す。この場合にも新生 時胸腺摘出群では 感染防御能の著しい低下が 観察され to.

[3] 日本脳炎ウイルス $(\mathrm{JEV})^{0)}$

ヒト用の日本脳炎ワクチンで CFI マウス急演した

表 4 . Mortality of Immunized Mice after Chal.

lenge with Ectromelia Virus (Single Shot).

\begin{tabular}{c|c|l|c}
\hline Strain & Immunization & Neonatal Op. & Mortality \\
\hline & \multirow{4}{*}{ Immunized } & Thymectomy & $5 / 5$ \\
CF $\# 1$ & & Sham-TE & $0 / 5$ \\
& \multirow{2}{*}{ Non-imm. } & Thymectomy & $7 / 7$ \\
& & Sham-TE & $7 / 7$ \\
\hline \multirow{3}{*}{ S L } & \multirow{2}{*}{ Immunized } & Thymectomy & $10 / 10$ \\
& & Sham-TE & $1 / 7$
\end{tabular}

表 5 Mortality of Immunized Mice after Challenge with Ectromelia Virus (Multiple shot)

\begin{tabular}{l|c}
\hline Neonatal Operation & Mortality \\
\hline Thymectomy & $8 / 8$ \\
Sham-thymectomy & $0 / 9$
\end{tabular}

表 6 Protection and Antibody Production in CF1 Mice Immunized with JEV Vaccine (Three Shots).

\begin{tabular}{c|c|c}
\hline Group & Mortality & HI Titers \\
\hline T E & $9 / 9$ & $\begin{array}{l}<10,<10,<10,<10,<10 \\
<10,<10,<10,<10\end{array}$ \\
\hline S H & $10 / 13$ & $\begin{array}{l}<10,<10,<10,<10,20,40 \\
40,40,40,40,40,40,80,80\end{array}$ \\
\hline Non-imm. & $4 / 4$ & $<10,<10,<10,<10$
\end{tabular}

表 7 Protection and Antibody Production in CF1 Mice Immunized with JEV Vaccine (Six Shots).

\begin{tabular}{c|c|c}
\hline Group & Mortality & HI Titers \\
\hline T E & $8 / 9$ & $<10,<10,<10,<10,<10,80$ \\
\hline S H & $2 / 12$ & $\begin{array}{c}<10,<10,40,40,80,80, \\
80,80,160,160,<320\end{array}$ \\
\hline Non-imm. & $3 / 3$ & $<10,<10,<10,<10,<10$
\end{tabular}

場合の血球凝集抑制抗体 (HI 抗体) の産生と, $10^{2.5} \mathrm{LD}_{50}$ の NIH-Nakayama 株 JEV で脳内攻撃を行なつた場合 の死亡率を表 6 （3回接種）および表 7 (6 回接種)に示 す。 JEV の場合に注，頻回免疫を行なつたにもかかわ らず，新生時脑腺摘出群で注殆んど HI 抗体の産生が られなかつた。また，HI 抗体産生への影響にほぼ一致 して, 感染防御免疫も新生時胸腺摘出群で注殆えど得ら れなかつた。

\section{[4] $\mathrm{LCM}{ }^{(2)}$}

LCM に扮けるマウスの死因沙ウイスス堌殖それ自 体ではなく，ウイルスの脉内堌殖とその結果脳内で拉こ る遅延型過敏症反応にもとづくことが汪ぼ明らかにされ ている，新生時胸腺摘出マウスでは遅延型過敏症が抑制! されるので，LCM ウイルス湆殖するにもかかわらず マウスは死亡变次礼る。宝た，LCM ウイルスを足 踣に接種した場合には，ウイルスの增殖後遅延型過敏に もとづく足蹠反応を肉眼的に観察することができるが， この反応も新生時胸腺摘出マウスでは抑制された。この ように防御機能の低下とは逆に感染症にお打る発症が阻 止される例があることは興味梁い.

\section{むすび}

以上いくつかのウイルス髠染症に损いて新生時胸腺摘 出の影響について検討した，免没能の発達に怙汀る胸腺 の役割の点から，新生時胸腺摘出の感染症における影響 を二つに分けることができる。

(1) 免疫能の低下のために，感染防御能が低下し発症 
が促進寺る場合。

(2) 遅延型過敏症が発症の本態である例で注その反応 の低下のた好にかえつて発症が抑制される場合。

感染防御能低下につマて性 JEV の場合の上うに血中 抗体と感染防御能が平行寸る例も市つ\%，HSV の場合， 新生時胸腺摘出群伛おいても中和抗体の産生がみられた が，感染防御能は新生時胸腺摘出群に招いて著しく低下 していた，このように，新生時胸腺摘出は，感染防御能 の本態の解析に重要な手段を提供するものと思われる。

\section{文 献}

1) 武谷, 森: 科学 35，371-376 (1965), -2) 森: 最新医学，20，2711-2717 (1965)。-3) 森：ウイ ルス学の進展 (1965) pp. 154-168. -4) Mori, R., Tasaki, T., Kimura, G., and Takeya, K. : Arch. Virusforschung (in press). - -5) Mori, R.,Kimoto, K., and Takeya,K. : (in preparation). -6) Mori, R., Kimoto, K., Takeya, K, and Otsuka, S. : (in preparation). -7) Mori, R., Nomoto, K., and Takeya, K. : Proc. Japan Acad. 40, 772775 (1965).

\section{5. 風疹ウイルスの胎內感染と抗体産生}

九大小児科

植 田浩司

妊娠初期に妊婦が風疹に罹患すると，先天異常を衫こ すことはよく知られた臨床的事実であり，その異常を先 天性風疹症候群とよんでいる。先天性風疹症候群はウイ ルス胎内感染という免疫学的にきわめて興味ある対象で 亦当。

妊娠初期に妊婦が 風疹に罹患するとウイレミアがお こり, 胎児に感染する,胎内児に江娃娠中はもとより，出 生後も1年間ぐらいまで風疹ウイルスが存続する，風疹 中和抗体は母親由来の抗体が消失する生後 6 力月以後も 高、值を示す，すなわち風疹の子宮内感染注免疫学的耐 性を生じない，風疹中和抗体ははじぬ IgG（7S）抗体が 主であるが，生後4～７另月に注患児の産生する IgM

(19S) 抗体がピークになり，生後 12 力月にまで存続す る. 生後 10 力月頃から注患児の産生する $\operatorname{IgG}$ 抗体が再 び優勢となり，生後12力月以後法これの外存続する，以 上のウイルス学的, 免疫学的現象が先天性風疹症候群の 実験室㟝断に応用されているが，私たちの経験した症例 につき検討した成績を報告する。

風疹罹患胎児 3 例（妊娠 7 週に罹患し妊娠 12 週に人 工流産した 1 例, 妊娠 8 週に罹患し妊娠 13 週に人工流産
した 2 例）よりウイルス分離を行なつたところ妊娠 8 週 に羅患した 2 例の胎児から風疹ウイルスが分離された。

風疹中和抗体について，母親が妊娠中に風疹に罹患し たもの 57 例，このうち先天性風疹症候群と診断された すの 47 例，正常と思われるもの 10 例，また舟親に風疹 羅患の既往はないが定型的な先天性風疹症候群の症状索 呈したもの 4 例, 刘照として心疾患 10 例，白内障・脳 性麻瘦および正常児それぞれ1例計 74 例のこどもと， 9 例を除くそれぞれの母親 65 例総計 139 例について風 疹中和抗体洒測定した．母親に風疹罹恵の既往がある 先天性風疹症候群のこどもは 47 例中 42 例が陽性，正常 と思わ机るものは 10 例中 4 例が陽性であつた。親に風 疹罹患の既往はないが; 型型的な先天性風疹症候群の症 状を呈したこどむたら，恐らく注不顕性感染によるもの と思われる 4 例は全例陽性であつた。 また心臟病，正常 児にも陽性を示した例があつた：これら患者の咽頭ぬぐ い液，尿などを材料としてウイルス分離をこころみたが 3 代継代しても全例干涉除性で分離怯不成功に終つた。

この成績を母親とこどもの関係，母親の罹患した娃 娠月数，こどもの年齢について検討すると，母親に風疹 の既往がある場合は，母子ともに2 倍以下を示す 1 組を 除いて他の母親は全例高い価を示したがそのこどもたち 洗天性風疹症候群 41 例中 36 例が高く， 5 例は 2 倍以 下を示した． 宗た，正常で生れたもののうち 3 例が 8 倍 以上を示しました。

母親に 風疹羅患の 既往が無い場合は定型的な 先天性 風疹症候群の診断をららゔけている。疾患 9 例中 2 例 が母子とも高く，このうち 1 例怯同じ頃先天性風疹症候 群の患者が多数生れていることから，不顕性感染による 先天性風疹症候群と推定される症例である，母親が羅患 したときの妊娠月数との関係をみると，3 力月以前に䍜 患したものが，高、傾向がみられる，先天性風疹症候群 のうち 2 倍以下を示寸 5 例はいずれも心臟病のみの症例 で特に 6 力月以降汇罹患した 3 例は先天性風疹症候群か ら除いても良い症例と思わ就る。こどもの年齢の関係 注，先天性風疹症候群の患児梳 5 力月から 12 力月の間 で高い価を示した。

以上の成績加ら，風疹の胎内感染怯免疫学的耐性を 生じないこと，そしてこれが先天性風疹症候群の実験診 断に意義が大であることが私たちの症例でも示された。 さらにこれらの症例につき各種抗体の消長と経過䘮扮つ て観察して河きたい。 